In Cooperation with the National Park Service

\title{
Preliminary Geochemical Assessment of Water from Selected Streams, Springs, and Caves in the Upper Baker and Snake Creek Drainages in Great Basin National Park, Nevada, 2009
}

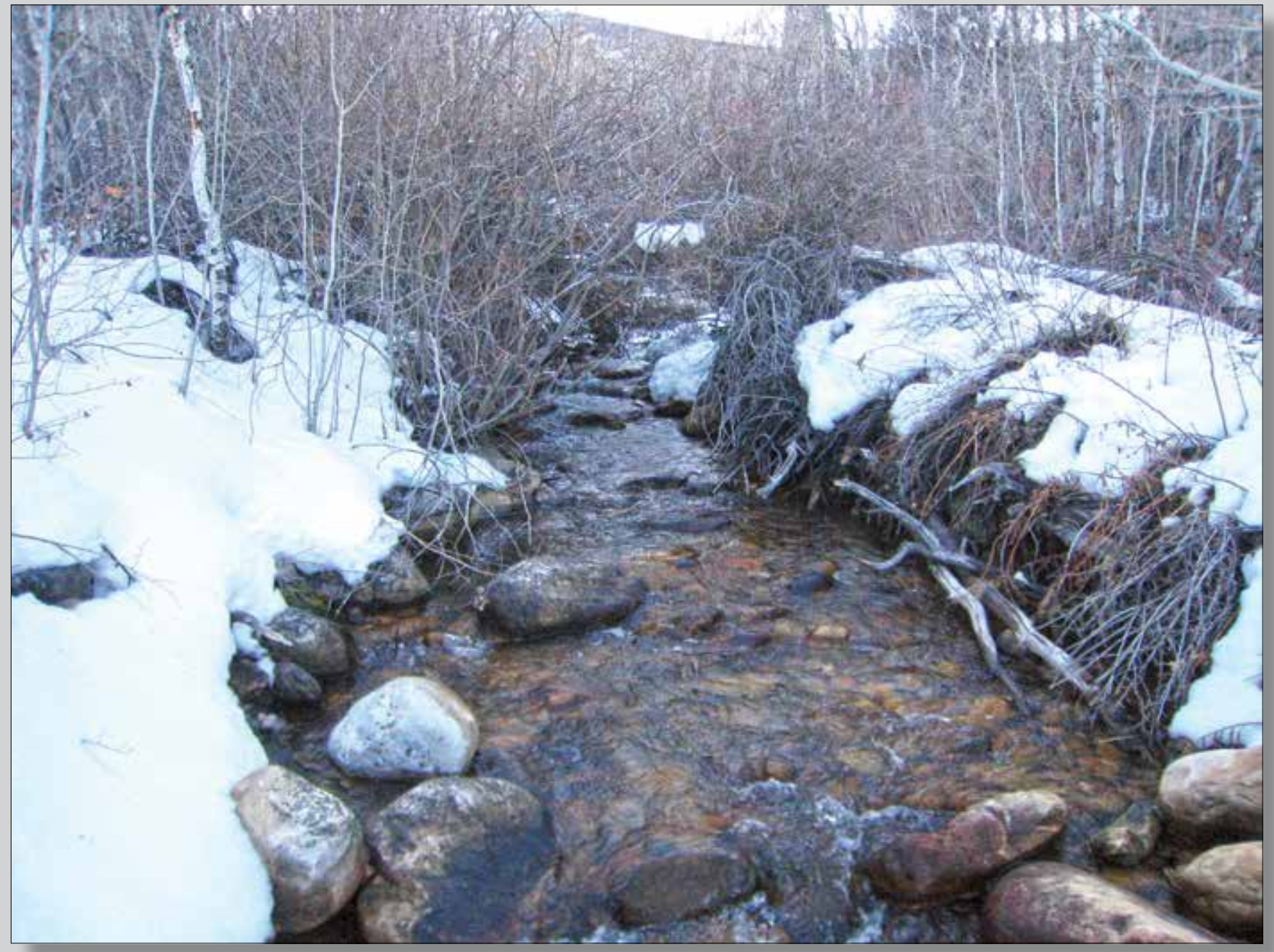

Scientific Investigations Report 2014-5108 
Cover art: Photograph of Baker Creek above "the Narrows", Great Basin National Park, Nevada. Photograph by Dave Prudic, U.S. Geological

Survey, February 2009. 


\section{Preliminary Geochemical Assessment of Water from Selected Streams, Springs, and Caves in the Upper Baker and Snake Creek Drainages in Great Basin National Park, Nevada, 2009}

By Angela P. Paul, Carl E. Thodal, Gretchen M. Baker, Michael S. Lico, and David E. Prudic

In Cooperation with the National Park Service

Scientific Investigations Report 2014-5108 


\title{
U.S. Department of the Interior SALLY JEWELL, Secretary
}

\section{U.S. Geological Survey \\ Suzette M. Kimball, Acting Director}

\author{
U.S. Geological Survey, Reston, Virginia: 2014
}

For more information on the USGS - the Federal source for science about the Earth, its natural and living resources, natural hazards, and the environment, visit http://www.usgs.gov or call 1-888-ASK-USGS.

For an overview of USGS information products, including maps, imagery, and publications, visit http://Www.usgs.gov/pubprod.

To order this and other USGS information products, visit http://store.usgs.gov.

Any use of trade, firm, or product names is for descriptive purposes only and does not imply endorsement by the U.S. Government.

Although this information product, for the most part, is in the public domain, it also may contain copyrighted materials as noted in the text. Permission to reproduce copyrighted items must be secured from the copyright owner.

Suggested citation:

Paul, A.P., Thodal, C.E., Baker, G.M., Lico, M.S., and Prudic, D.E., 2014, Preliminary geochemical assessment of water in selected streams, springs, and caves in the Upper Baker and Snake Creek drainages in Great Basin National Park, Nevada, 2009: U.S. Geological Survey Scientific Investigations Report 2014-5108, 33 p. http://dx.doi.org/10.3133/ sir20145108

ISSN 2328-0328 (online) 


\section{Contents}

Abstract
Introduction
Purpose and Scope
Description of Study Area
Baker Creek Watershed
Snake Creek Watershed
Methods
Measurement of Physical and Chemical Parameters
$\quad$ Anallection of Water Samples of Water Samples
Anallection of Rock Samples of Rock Samples
$\quad$ Uuality Assurance
$\quad$ Recharge Altitude
$\quad$ Residence Time




\section{Figures}

1. Map showing locations of the upper Baker and Snake Creek drainages in Great Basin National Park, White Pine County, Nevada

2. Map showing geology of the study area and locations of selected streams, springs, and caves from which water and rock samples were collected in the upper Baker and Snake Creek drainages in Great Basin National Park, Nevada, February 2009

3. Map showing location of the bypass pipeline, Squirrel Spring Cave, and sampling locations from which selected water and rock samples were collected in the upper Snake Creek drainage in Great Basin National Park, Nevada, February 2009

4. Graphs showing delta deuterium and delta oxygen-18 values in $A$, local precipitation and water samples collected from selected streams, springs, and caves in the upper Baker and Snake Creek drainages in Great Basin National Park, Nevada, February 2009 , and $B$, expanded view of water samples in relation to the local and global meteoric water lines

5. Graph showing relation between specific conductance and sum-of-constituents in water samples collected from selected streams, springs, and caves in the upper Baker and Snake Creek drainages in Great Basin National Park, Nevada, February 2009

6. Graph showing relation between calcium and magnesium to bicarbonate concentrations in water samples collected from selected streams, springs, and caves in the upper Baker and Snake Creek drainages in Great Basin National Park, February 2009 .... 13

7. Ternary plots showing the distribution of general water-chemistry characteristics using selected major-ion concentrations in water samples collected from selected streams, springs, and caves in the upper Baker and Snake Creek drainages in Great Basin National Park, Nevada, February 2009 ...

8. Graph showing relation between delta carbon-13 values and bicarbonate and carbon dioxide concentrations in water samples collected from selected streams, springs, and caves in the upper Baker and Snake Creek drainages in Great Basin National Park, Nevada, February 2009

9. Graph showing relation between strontium concentration and strontium-87 to strontium-86 isotope ratios in water and rock samples collected from selected sites in the upper Baker Creek drainage in Great Basin National Park, February 2009

10. Graphs showing relation between uranium concentration and isotope ratio $\left({ }^{234} \mathrm{U} /{ }^{238} \mathrm{U}\right)$ in water samples collected from selected streams, springs, and caves in the $A$, upper Baker, and $B$, upper Snake Creek drainages in Great Basin National Park, Nevada, February 2009

11. Map showing location of sampling sites and the extent of Wheelers Deep and Model Caves in relation to Baker and Pole Canyon Creeks in the upper Baker Creek drainage, Great Basin National Park, Nevada

12. Graphs showing comparison of $A$, chloride concentration, and $B$, delta deuterium and delta oxygen-18 values in water collected from selected streams, springs, and caves in the upper Baker Creek and Snake Creek watersheds in Great Basin National Park, Nevada, February 2009.

13. Graph showing relation between strontium concentration and strontium-87 to strontium-86 isotope ratios in water and rock samples collected from selected sites in the upper Snake Creek drainage in Great Basin National Park, February 2009 


\section{Tables}

1. Site identification, location, and altitude of selected streams, springs, and caves from which water and rock samples were collected in the upper Baker and Snake Creek drainages in Great Basin National Park, Nevada, February 2009 5

2. Carbon, oxygen, and strontium isotope ratios in rock samples collected near selected streams and caves in the upper Baker and Snake Creek drainages in Great Basin National Park, Nevada, February 2009

3. Carbon, hydrogen, oxygen, strontium, and uranium isotope ratios in water samples collected from selected streams, springs, and caves in the upper Baker and Snake Creek drainages in Great Basin National Park, Nevada, February 2009

4. Concentration of chlorofluorocarbons and dissolved gases in water samples collected from selected streams, springs, and caves in the upper Baker and Snake Creek drainages in Great Basin National Park, Nevada, February 2009

5. Temperature boundary conditions for estimating recharge altitude based on temperature of melting ice and decrease in air temperature with increasing altitude

6. Estimated recharge altitudes, temperatures, and excess air concentrations for selected sites in the upper Baker and Snake Creek drainages in Great Basin National Park, Nevada, February 2009

7. Estimated recharge temperatures and age of waters as determined using dissolved gases and chlorofluorocarbons for water samples collected from selected springs and caves in the upper Baker and Snake Creek drainages in Great Basin National Park, Nevada, February 2009

Appendix 1

1-1. Summary of certificate of analysis for blank water used to process equipment blanks associated with sampling water from selected streams, springs, and caves in the upper Baker and Snake Creek drainages in Great Basin National Park, Nevada, February 2009

Appendix 2

2-1. Concentrations of constituents analyzed in water samples collected from selected streams, springs, and caves in the upper Baker and Snake Creek drainages in Great Basin National Park, Nevada, February 2009

2-2. Elemental composition of rock samples collected from selected sites in Great Basin National Park, Nevada, February 2009 


\section{Conversion Factors, Datums, and Water-Quality Units}

Inch/Pound to SI

\begin{tabular}{|c|c|c|}
\hline Multiply & By & To obtain \\
\hline \multicolumn{3}{|c|}{ Length } \\
\hline foot $(\mathrm{ft})$ & 0.3048 & meter $(\mathrm{m})$ \\
\hline mile (mi) & 1.609 & kilometer $(\mathrm{km})$ \\
\hline \multicolumn{3}{|c|}{ Area } \\
\hline square mile $\left(\mathrm{mi}^{2}\right)$ & 2.590 & square kilometer $\left(\mathrm{km}^{2}\right)$ \\
\hline \multicolumn{3}{|c|}{ Volume } \\
\hline gallon (gal) & 3.785 & liter $(\mathrm{L})$ \\
\hline \multicolumn{3}{|c|}{ Flow rate } \\
\hline cubic foot per second $\left(\mathrm{ft}^{3} / \mathrm{s}\right)$ & 0.02832 & cubic meter per second $\left(\mathrm{m}^{3} / \mathrm{s}\right)$ \\
\hline
\end{tabular}

Chemical concentrations and activities, volumes of water, and mass of rocks collected for analyses are reported in SI units.

SI to Inch/Pound

\begin{tabular}{|c|c|c|}
\hline Multiply & By & To obtain \\
\hline \multicolumn{3}{|c|}{ Excess air concentration } \\
\hline cubic centimeter per liter $\left(\mathrm{cm}^{3} / \mathrm{L}\right)$ & 0.2310 & cubic inch per U.S. gallon (in $3 /$ gal) \\
\hline \multicolumn{3}{|c|}{ Chemical concentration } \\
\hline milligram per kilogram $(\mathrm{mg} / \mathrm{kg})$ & 0.0070 & grain per pound (gr/lb) \\
\hline milligram per kilogram $(\mathrm{mg} / \mathrm{kg})$ & 0.05841 & grain, avoirdupois per gallon (gr/gal) \\
\hline picogram per kilogram (pg/kg) & $7.0 \times 10^{-12}$ & grain per pound (gr/lb) \\
\hline \multicolumn{3}{|c|}{ Radioactivity } \\
\hline picocurie per liter $(\mathrm{pci} / \mathrm{L})$ & 0.037 & Becquerel per liter $(\mathrm{Bq} / \mathrm{L})$ \\
\hline \multicolumn{3}{|c|}{ Volume } \\
\hline cubic centimeter $\left(\mathrm{cm}^{3}\right)$ & 0.06102 & cubic inch $\left(\right.$ in $\left.^{3}\right)$ \\
\hline liter $(\mathrm{L})$ & 0.2642 & U.S. gallon (gal) \\
\hline milliliter $(\mathrm{ml})$ & 0.001057 & quart $(\mathrm{qt})$ \\
\hline \multicolumn{3}{|c|}{ Flow rate } \\
\hline liter per minute (L/min) & 0.2642 & gallon per minute (gal/min) \\
\hline \multicolumn{3}{|c|}{ Mass } \\
\hline picogram (pg) & $1.543 \times 10^{-11}$ & grain, avoirdupois (gr) \\
\hline milligram (mg) & 0.01543 & grain, avoirdupois (gr) \\
\hline $\operatorname{gram}(\mathrm{gm})$ & 0.03527 & ounce, avoirdupois (oz) \\
\hline kilogram (kg) & 2.205 & pound, avoirdupois (lb) \\
\hline
\end{tabular}

Temperature in degrees Celsius $\left({ }^{\circ} \mathrm{C}\right)$ may be converted to degrees Fahrenheit $\left({ }^{\circ} \mathrm{F}\right)$ as follows:

${ }^{\circ} \mathrm{F}=\left(1.8 \times{ }^{\circ} \mathrm{C}\right)+32$

Temperature in degrees Fahrenheit $\left({ }^{\circ} \mathrm{F}\right)$ may be converted to degrees Celsius $\left({ }^{\circ} \mathrm{C}\right)$ as follows:

${ }^{\circ} \mathrm{C}=\left({ }^{\circ} \mathrm{F}-32\right) / 1.8$

Vertical coordinate information is referenced to the North American Vertical Datum of 1988 (NAVD 88). 
Horizontal coordinate information is referenced to the North American Datum of 1983 (NAD 83).

Specific conductance is given in microsiemens per centimeter at 25 degrees Celsius $(\mu \mathrm{S} / \mathrm{cm}$ at $\left.25^{\circ} \mathrm{C}\right)$.

Concentrations of chemical constituents in water are given either in milligrams per liter (mg/L), micrograms per liter $(\mu \mathrm{g} / \mathrm{L})$, or picograms per kilogram $(\mathrm{pg} / \mathrm{kg})$. Concentrations of isotopes in

water samples are reported as a ratio of one isotope to another or in permil $(\% \circ)$. Concentrations of chemical constituents in rocks are reported in grams per kilogram $(\mathrm{g} / \mathrm{kg})$.

\section{ABBREVIATIONS}

BCB Baker Creek above B-loop crossing

CFC Chlorofluorocarbon

CFC-11 Trichlorofluoromethane

CFC-12 Difluorodichloromethane

CFC-113 1,1,2-Trichloro-1,2,2-trifluoroethane

DIC Dissolved inorganic carbon

DO Dissolved oxygen

DOC Dissolved organic carbon

DOE Department of Energy

ICP-MS Inductively coupled plasma-mass spectrometry

IUPAC International Union of Pure and Applied Chemistry

LR Lapse rate

MOC Model Cave

NBS-19 calcite (crushed marble) reference material

NFQA National Field Quality Assurance (Program)

NIST National Institute of Standards and Technology

NRC National Research Council

NWIS National Water Information System (database)

NWQL National Water Quality Laboratory

OHS Outhouse Spring

OLS Outlet Spring

PCC Pole Canyon Creek

PDB Pee Dee Formation belemnite

RTS Rosethorn Spring

SAO Snake Creek above Outhouse Spring

SOP Snake Creek at outlet of pipeline

SPS Spring Creek Spring

SRM Standard reference material

SRW Standard reference water

SSC Squirrel Spring Cave

TS-1 TS-limestone

VPDB Vienna Pee Dee belemnite

VSLAP Vienna Standard Light Antarctic Precipitation

VSMOW Vienna Standard Mean Ocean Water

WDC Wheelers Deep Cave

YMPL Yucca Mountain Project Laboratory 


\title{
Preliminary Geochemical Assessment of Water from Selected Streams, Springs, and Caves in the Upper Baker and Snake Creek Drainages in Great Basin National Park, Nevada, 2009
}

\author{
By Angela P. Paul, Carl E. Thodal, Gretchen M. Baker, Michael S. Lico, and David E. Prudic
}

\begin{abstract}
Water in caves, discharging from springs, and flowing in streams in the upper Baker and Snake Creek drainages are important natural resources in Great Basin National Park, Nevada. Water and rock samples were collected from 15 sites during February 2009 as part of a series of investigations evaluating the potential for water resource depletion in the park resulting from the current and proposed groundwater withdrawals. This report summarizes general geochemical characteristics of water samples collected from the upper Baker and Snake Creek drainages for eventual use in evaluating possible hydrologic connections between the streams and selected caves and springs discharging in limestone terrain within each watershed.

Generally, water discharging from selected springs in the upper Baker and Snake Creek watersheds is relatively young and, in some cases, has similar chemical characteristics to water collected from associated streams. In the upper Baker Creek drainage, geochemical data suggest possible hydrologic connections between Baker Creek and selected springs and caves along it. The analytical results for water samples collected from Wheelers Deep and Model Caves show characteristics similar to those from Baker Creek, suggesting a hydrologic connection between the creek and caves, a finding previously documented by other researchers. Generally, geochemical evidence does not support a connection between water flowing in Pole Canyon Creek to that in Model Cave, at least not to any appreciable extent. The water sample collected from Rosethorn Spring had relatively high concentrations of many of the constituents sampled as part of this study. This finding was expected as the water from the spring travelled through alluvium prior to being discharged at the surface and, as a result, was provided the opportunity to interact with soil minerals with which it came into contact. Isotopic evidence does not preclude a connection between Baker Creek and the water discharging from Rosethorn Spring. The residence time of water discharging into the caves and from selected springs sampled as part of this study ranged from 10 to 25 years.
\end{abstract}

Within the upper Snake Creek drainage, the results of this study show geochemical similarities between Snake Creek and Outhouse Spring, Spring Creek Spring, and Squirrel Spring Cave. The strontium isotope ratio $\left({ }^{87} \mathrm{Sr} /{ }^{86} \mathrm{Sr}\right)$ for intrusive rock samples representative of the Snake Creek drainage were similar to carbonate rock samples. The water sample collected from Snake Creek at the pipeline discharge point had lower strontium concentrations than the sample downstream and a similar ${ }^{87} \mathrm{Sr} /{ }^{86} \mathrm{Sr}$ value as the carbonate and intrusive rocks. The chemistry of the water sample was considered representative of upstream conditions in Snake Creek and indicates minimal influence of rock dissolution. The results of this study suggest that water discharging from Outlet Spring is not hydrologically connected to Snake Creek but rather is recharged at high altitude(s) within the Snake Creek drainage. These findings for Outlet Spring largely stem from the relatively high specific conductance and chloride concentration, the lightest deuterium $(\delta \mathrm{D})$ and oxygen-18 $\left(\delta^{18} \mathrm{O}\right)$ values, and the longest calculated residence time (60 to 90 years) relative to any other sample collected as part of this study. With the exception of water sampled from Outlet Spring, the residence time of water discharging into Squirrel Spring Cave and selected springs in the upper Snake Creek drainage was less than 30 years.

\section{Introduction}

Great Basin National Park encompasses about 120 square miles $\left(\mathrm{mi}^{2}\right)$ of the highest parts of the southern Snake Range, near the border with Utah in eastern White Pine County, Nevada. The range is bounded by Spring Valley to the west and Snake Valley to the east. Snake and Baker Creeks drain eastward from the southern Snake Range out of the park into Snake Valley (fig. 1). Water in caves, springs, and flowing in streams in the upper Baker and Snake Creek drainages are important natural resources in Great Basin National Park, 


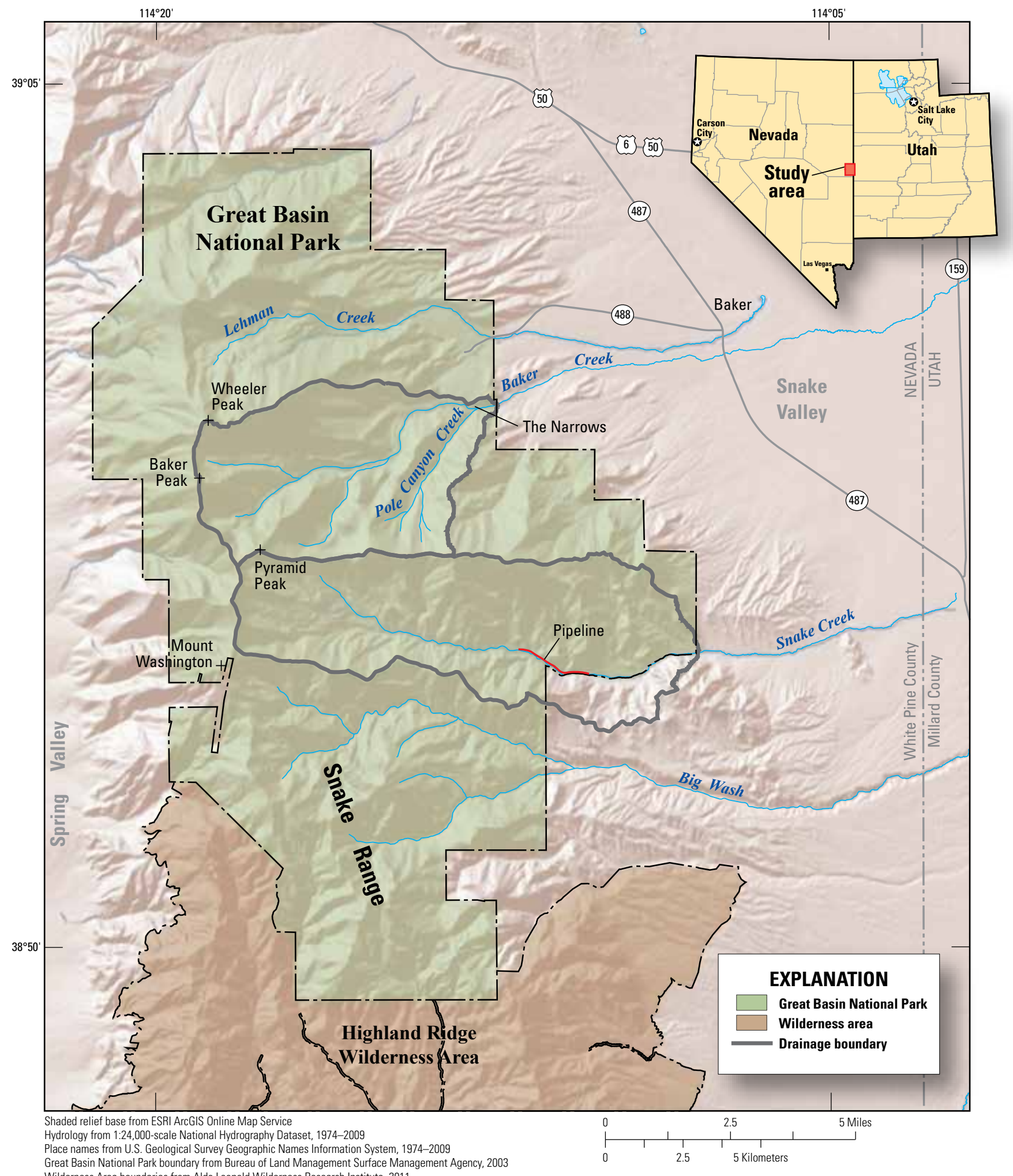

Great Basin National Park boundary from Bureau of Land Management Surface Management Agency, 2003

Universal Transverse Mercator Projection, Zone 11, NAD83

Figure 1. Locations of the upper Baker and Snake Creek drainages in Great Basin National Park, White Pine County, Nevada. 
sustaining flora and fauna in the area. Groundwater resources from basin-fill and carbonate-rock aquifers in Snake Valley are being considered as a potential water supply for southern Nevada and western Utah. However, these aquifers may also play an important role in maintaining the springs, streams, wetlands, limestone caves, and other biologically sensitive areas on Federal lands in eastern Nevada. A U.S. Geological Survey study commissioned by the National Park Service indicated that some areas in the Baker and Snake Creek drainages may be susceptible to groundwater withdrawals from Snake Valley (Elliott and others, 2006) causing concern that large-scale pumping of groundwater in Snake Valley might adversely affect the water resources in these drainages within Great Basin National Park.

\section{Purpose and Scope}

The purpose of this report is to present water and rock chemistry from samples collected at selected streams, springs, and caves in the upper Baker and Snake Creek drainages during February 2009. The report includes discussions on general principles and assessments of the chemical composition of water and rock samples that will eventually be used to evaluate sources of recharge and hydrologic connectivity among these features in Great Basin National Park. Water samples were analyzed for dissolved major ions, selected trace elements, dissolved gases and chlorofluorocarbons, and for isotopes of carbon, hydrogen, oxygen, strontium, and uranium. Two whole rock samples of Pole Canyon Limestone, collected from the Baker Creek drainage basin, and one sample each of Pogonip Group Limestone and Fish Haven/Laketown Dolomites collected from the Snake Creek drainage basin were analyzed for selected minor trace elements and the isotopic composition of carbon, oxygen, and strontium.

\section{Description of Study Area}

Most groundwater recharge available to aquifers within the valleys of the Great Basin originate as winter precipitation in mountain areas adjacent to them (Harrill and Prudic, 1998). Baker Creek and Snake Creek drain the two largest watersheds in Great Basin National Park with headwaters originating at altitudes of more than 11,000 feet (ft) above mean sea level within the southern Snake Range (fig. 1).

\section{Baker Creek Watershed}

Baker Creek has an entire drainage area of about $24.3 \mathrm{mi}^{2}$ with headwaters above $13,000 \mathrm{ft}$ on the south side of Wheeler Peak and lower drainages from Baker Peak and Pyramid Peak. The creek and its tributaries gain streamflow from the alluvial and glacial deposits that overly older granite, quartzite, and limestone (fig. 2; Elliott and others, 2006). Elliott and others (2006) report the mean annual discharge for Baker Creek to be about 9 cubic feet per second $\left(\mathrm{ft}^{3} / \mathrm{s}\right)$. Baker Creek narrows near the confluence of Baker Creek and Pole Canyon Creek. The drainage area of Baker Creek above the Narrows is $16.6 \mathrm{mi}^{2}$ (fig. 1; Elliott and others, 2006). Many of the limestone caves in the park are located along this reach of the creek (Lange, 1958). Downstream, where the Baker Creek channel crosses undifferentiated sedimentary rocks that include Pole Canyon Limestone, synoptic measurements indicate that nearly 50 percent of the streamflow may be lost by infiltration into the limestone rocks, likely part of the Baker Creek cave system (Elliot and others, 2006). The caves in the Baker Creek area, which include both Wheelers Deep and Model Caves, network through Pole Canyon Limestone (Bridgemon, 1966).

Sample sites 1-7 are located in the Baker Creek drainage (fig. 2; table 1). Water samples were collected from Baker and Pole Canyon Creeks (sites 1 and 3, respectively), two caves (sites 2 and 4), and one spring (site 5), and rock samples were collected from two outcrops of carbonate (Pole Canyon Limestone) rock (sites 6 and 7).

\section{Snake Creek Watershed}

The headwaters of Snake Creek drain from the north side of Mount Washington and the south side of Pyramid Peak with a drainage area in the park of about $22 \mathrm{mi}^{2}$ (Elliot and others, 2006). Quartzite and granite capped by alluvial and glacial deposits are the primary geologic units through which the headwater channel is cut (Elliot and others, 2006). Downstream of the intrusive rock outcrops is evidence of a major extensional deformation known as the southern Snake Range décollement (Misch and Hazzard, 1962; Whitebread, 1969). Researchers have renamed this décollement the Southern Snake Range detachment (Miller and others, 1999). The surface of this detachment lies between the older quartzite rocks and the overlying younger undifferentiated rocks.

In 1961, at the contact between the intruded granitic rock and the lower plate of the southern Snake Range detachment, a pipeline was constructed to convey about $3 \mathrm{ft}^{3} / \mathrm{s}$ of water from Snake Creek around a 3-mi section across the detachment (Elliott and others, 2006). The pipeline was constructed to avoid potential streamflow losses into the Pole Canyon Limestone in the area. At the downstream end of the pipeline, diverted water is released back into the channel of Snake Creek (fig. 3). Synoptic measurements made upstream and downstream of the pipeline in June 2003 indicated that about $2.6 \mathrm{ft}^{3} / \mathrm{s}$ of flow was lost to the natural channel adjacent to the pipeline (Elliot and others, 2006).

Sample sites 8-15 are located in the Snake Creek drainage (figs. 2, 3; table 1). Water samples were collected from one cave (site 8), at two locations along Snake Creek (sites 9 and 11), and from three springs (sites 10, 12, and 13). Two rock samples were obtained from outcrops: one near the entrance of Squirrel Spring Cave (Fish Haven/Laketown Dolomites, site 14) and one near Outhouse Spring (Pogonip Limestone, site 15). Lee and Van Loenen (1971) describe granitoid rocks in the Snake Creek drainage that have assimilated limestone. 


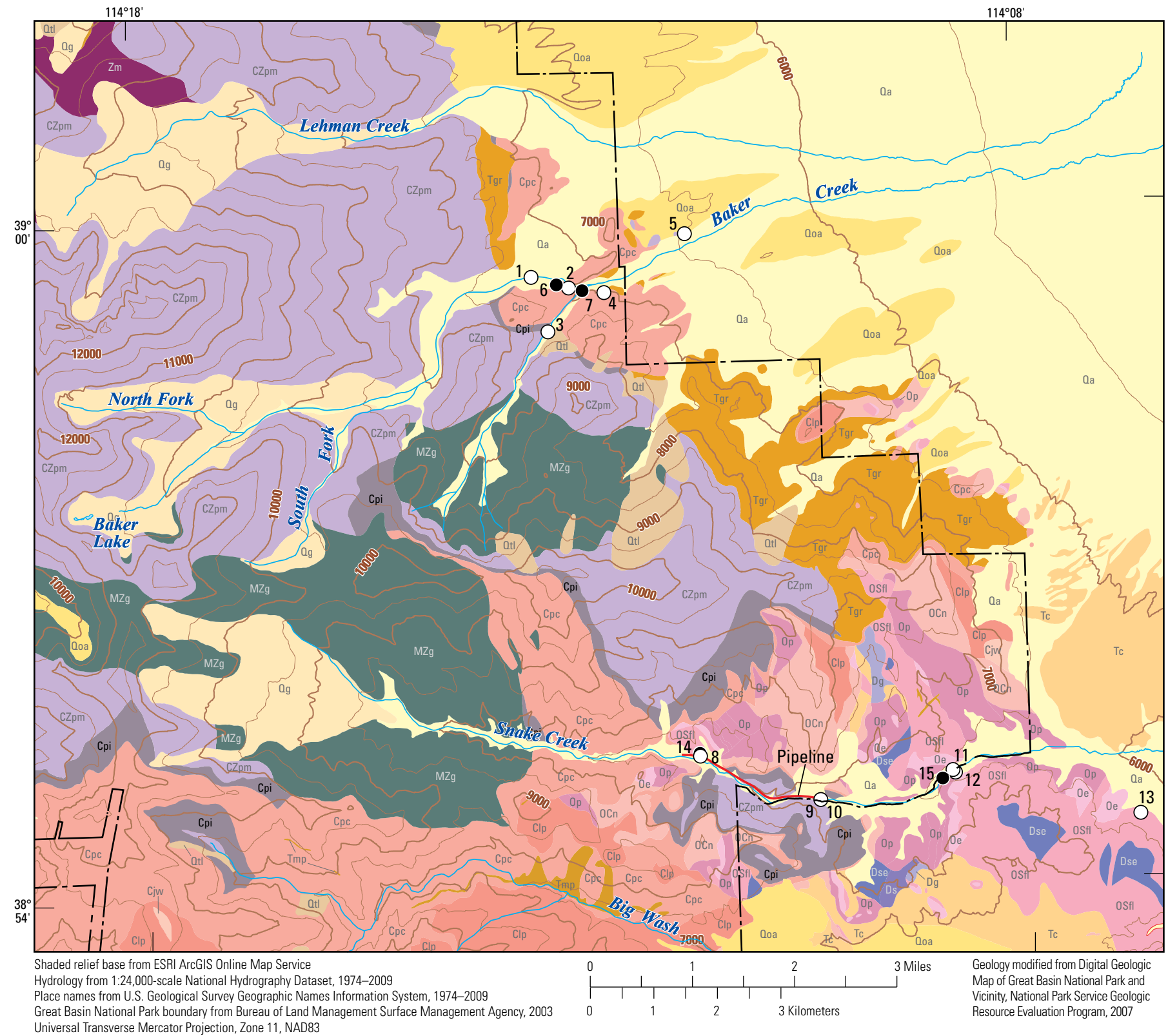

\section{EXPLANATION}

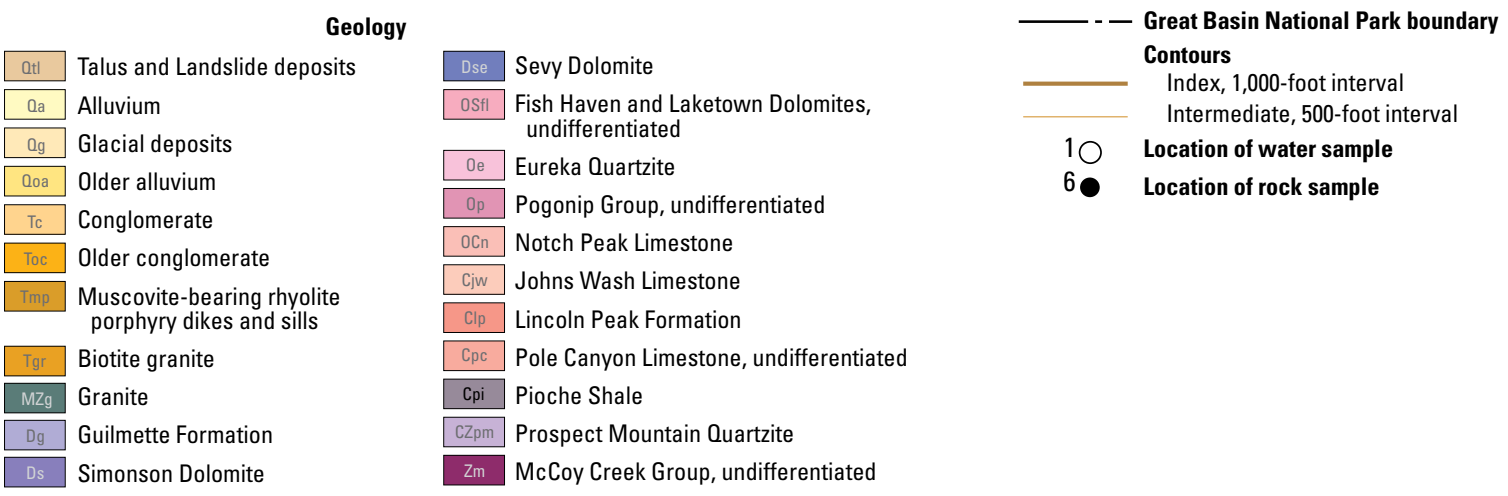

Figure 2. Geology of the study area and locations of selected streams, springs, and caves from which water and rock samples were collected in the upper Baker and Snake Creek drainages in Great Basin National Park, Nevada, February 2009. 
Table 1. Site identification, location, and altitude of selected streams, springs, and caves from which water and rock samples were collected in the upper Baker and Snake Creek drainages in Great Basin National Park, Nevada, February 2009.

[Abbreviations: ft, feet; ${ }^{\circ}$, degrees; ', minutes; ", seconds; - , not applicable]

\begin{tabular}{|c|c|c|c|c|c|}
\hline $\begin{array}{c}\text { Site } \\
\text { number }\end{array}$ & Site name and abbreviation & $\begin{array}{l}\text { Station identification } \\
\text { number }\end{array}$ & Latitude & Longitude & $\begin{array}{l}\text { Land-surface } \\
\text { altitude (ft) }\end{array}$ \\
\hline \multicolumn{6}{|c|}{ Baker Creek (water samples) } \\
\hline 1 & Baker Creek above B-loop crossing, Great Basin National Park (BCB) & 385928114144201 & $38^{\circ} 59^{\prime} 27.28^{\prime \prime}$ & $114^{\circ} 13^{\prime} 29.28^{\prime \prime}$ & 7,158 \\
\hline 2 & Wheelers Deep Cave (WDC) & 385921114130401 & $38^{\circ} 59^{\prime} 21.0^{\prime \prime}$ & $114^{\circ} 13^{\prime} 04.0^{\prime \prime}$ & 6,977 \\
\hline 3 & Pole Canyon Creek at trail crossing (PCC) & 385858114131901 & $38^{\circ} 58^{\prime} 58.0^{\prime \prime}$ & $114^{\circ} 13^{\prime} 19.0^{\prime \prime}$ & 7,171 \\
\hline 4 & Model Cave (MOC) & 385918114124001 & $38^{\circ} 59^{\prime} 18.0^{\prime \prime}$ & $114^{\circ} 12^{\prime} 40.0^{\prime \prime}$ & 7,000 \\
\hline 5 & Rosethorn Spring (RTS) & 385948114114401 & $38^{\circ} 59^{\prime} 48.0^{\prime \prime}$ & $114^{\circ} 11^{\prime} 44.0^{\prime \prime}$ & 6,460 \\
\hline \multicolumn{6}{|c|}{ Baker Creek (rock samples) } \\
\hline 6 & $\begin{array}{l}\text { Pole Canyon Limestone, west facing outcrop at Grey Cliffs east side of } \\
\text { Baker Creek at Ice Cave }\end{array}$ & - & $38^{\circ} 59^{\prime} 24.5^{\prime \prime}$ & $114^{\circ} 13^{\prime} 13.5^{\prime \prime}$ & - \\
\hline 7 & $\begin{array}{l}\text { Pole Canyon Limestone, north facing outcrop east side of Pole Canyon } \\
\text { Creek near confluence with Baker Creek }\end{array}$ & - & $38^{\circ} 59^{\prime} 18.2^{\prime \prime}$ & $114^{\circ} 12^{\prime} 55.02^{\prime \prime}$ & - \\
\hline \multicolumn{6}{|c|}{ Snake Creek (water samples) } \\
\hline 8 & Squirrel Spring Cave (SSC) & 385510114114401 & $38^{\circ} 55^{\prime} 10^{\prime \prime}$ & $114^{\circ} 11^{\prime} 44^{\prime \prime}$ & 7,200 \\
\hline 9 & Snake Creek at outlet of pipeline (SOP) & 385445114102302 & $38^{\circ} 54^{\prime} 45^{\prime \prime}$ & $114^{\circ} 10^{\prime} 23^{\prime \prime}$ & 6,755 \\
\hline 10 & Outlet Spring (OLS) & 385445114102301 & $38^{\circ} 54^{\prime} 45^{\prime \prime}$ & $114^{\circ} 10^{\prime} 23^{\prime \prime}$ & 6,755 \\
\hline 11 & Snake Creek above Outhouse Spring (SAO) & 385508114064501 & $38^{\circ} 54^{\prime} 58.08^{\prime \prime}$ & $114^{\circ} 08^{\prime} 51.74^{\prime \prime}$ & 6,389 \\
\hline 12 & Outhouse Spring (OHS) & 385456114085501 & $38^{\circ} 54^{\prime} 57.31^{\prime \prime}$ & $114^{\circ} 08^{\prime} 50.8^{\prime \prime}$ & 6,396 \\
\hline 13 & Spring Creek Spring (SPS) & 385433114063901 & $38^{\circ} 54^{\prime} 32.9^{\prime \prime}$ & $114^{\circ} 06^{\prime} 45.6^{\prime \prime}$ & 6,191 \\
\hline \multicolumn{6}{|c|}{ Snake Creek (rock samples) } \\
\hline 14 & $\begin{array}{l}\text { Fish Haven/Laketown Dolomites, south facing outcrop, north side of Snake } \\
\text { Creek near entrance to Squirrel Cave }\end{array}$ & - & $38^{\circ} 55^{\prime} 10.7^{\prime \prime}$ & $114^{\circ} 11^{\prime} 44.3^{\prime \prime}$ & - \\
\hline 15 & $\begin{array}{l}\text { Pogonip Group Limestone, north facing outcrop south side of Snake Creek } \\
\text { near Outhouse Spring }\end{array}$ & - & $38^{\circ} 54^{\prime} 53.7^{\prime \prime}$ & $114^{\circ} 08^{\prime} 59.7^{\prime \prime}$ & - \\
\hline
\end{tabular}




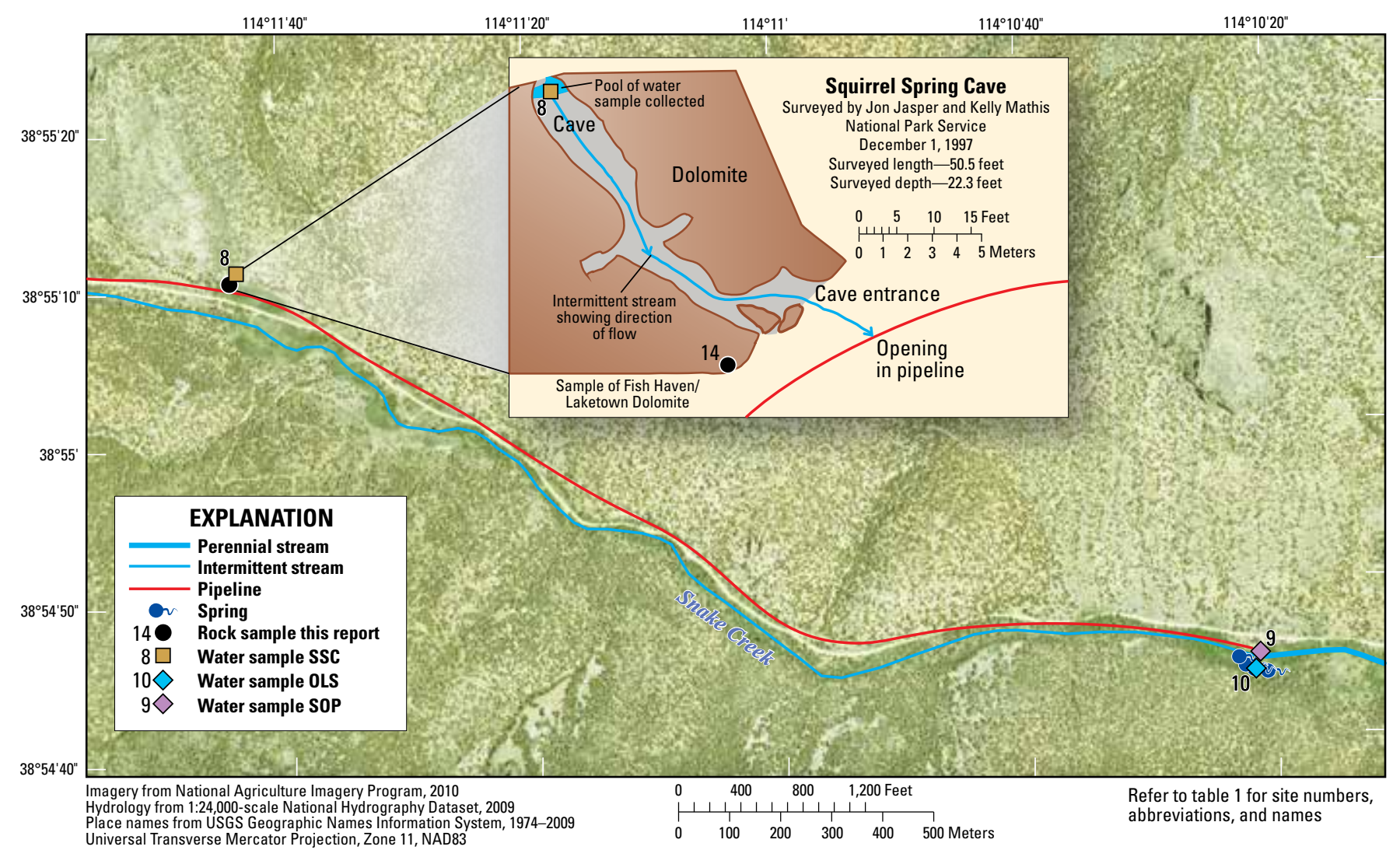

Figure 3. Location of the bypass pipeline, Squirrel Spring Cave, and sampling locations from which selected water and rock samples were collected in the upper Snake Creek drainage in Great Basin National Park, Nevada, February 2009.

\section{Methods}

Sampling sites in both the upper Baker and Snake Creek drainages were selected on the basis of their proximity to carbonate rocks. Chosen sites were located as far upstream of outcropping carbonates as possible so that the water chemistry in streams minimally influenced by these rocks could be evaluated. Samples were collected during baseflow conditions. The Baker Creek site was selected upstream of Wheelers Deep and Model Caves because of its possible hydrologic connection with the caves.

Collection of water samples generally followed standard USGS sampling protocols. All water samples were analyzed for field parameters (alkalinity, dissolved oxygen, $\mathrm{pH}$, specific conductance, and temperature); major ions; selected trace elements; dissolved organic carbon (DOC); and isotopes of oxygen, hydrogen, strontium, carbon, and uranium. Water collected from caves and springs also was analyzed for dissolved gases (argon, carbon dioxide, methane, and nitrogen) and chlorofluorocarbons (CFC-11, CFC-12, and CFC-113). Rock samples were analyzed for selected major and trace elements and stable isotopes of carbon, oxygen, and strontium. Samples were analyzed for chemical composition by the USGS National Water Quality Laboratory (NWQL) and the Yucca Mountain Project Laboratory (YMPL) in Denver, Colorado. Data obtained from this investigation are stored in the USGS National Water Information System (NWIS) database.

\section{Measurement of Physical and Chemical Parameters}

Field measurements were taken in accordance with protocols published in the USGS National Field Manual (Radtke and others, 2005; Lewis, 2006; Rounds, 2006; Wilde, 2006; Gibs and others, 2007; Ritz and Collins, 2008). Most field parameters (water temperature, specific conductance, $\mathrm{pH}$, dissolved oxygen) were measured using a YSI 6600 multiparameter sonde at all sites except the three caves. Parameters were measured at cave sites using a YSI 85 multiparameter sonde with probes that were submerged near the deepest part of the spring pool in each of two caves (Model and Squirrel Spring Caves) and in a flowing stream in Wheelers Deep Cave. A hole had to be dug under the cobble substrate in Model Cave in order to accommodate the YSI 85 probes. Measurements of $\mathrm{pH}$ for cave water were made with an Oakton pHTester. Air temperature was measured with an alcohol-filled thermometer and barometric pressure measured using a barometer. The sonde and meters were calibrated to appropriate standards upon arrival at each site. At spring sites, the calibrated sonde was deployed and temperature, dissolved oxygen, $\mathrm{pH}$, and specific-conductance values recorded at 5-minute intervals for at least 30 minutes until measurements were stable for three consecutive readings at which time water samples were collected. Filtered water samples were collected from each 
site for the determination of alkalinity using a digital titrator within 24 hours of sample collection. Samples were kept chilled until analysis.

\section{Collection of Water Samples}

Stream samples were collected by dip from the centroid of flow and individual dips composited into a plastic churn; spring samples were collected at the orifice. Both spring and stream samples were processed using a portable peristaltic pump equipped with tubing that was cleaned prior to collection of each sample following standard and modified USGS National Field Manual protocols (Koterba and others, 1995; Wilde and others, 2004; U.S. Geological Survey, 2006). The sampling protocols ensured that representative samples were collected and that samples were collected in a manner that minimized the potential for contamination.

All sample bottles, except those intended for the analysis of DOC, stable isotopes, dissolved gases, and CFCs, were polyethylene and pre-rinsed with deionized water. Immediately before collecting a sample, the bottles were rinsed three times with either unfiltered or filtered native water at the sampling site. Filtered samples were processed by pumping sample water through an inline, 0.45 -micron pore-size vented capsule filter, fitted to the sample tubing (Wilde, 1999; Wilde and others, 2004). Samples for trace element analysis were collected in an acid-rinsed polyethylene bottle and acidified to a $\mathrm{pH}$ of 2 or less with 7.7 normal (N) ultrex nitric acid. One 250-milliliter $(\mathrm{ml})$ polyethylene bottle was filled with unfiltered native water for laboratory analysis of specific conductance and $\mathrm{pH}$.

Water samples for DOC were collected in $125-\mathrm{ml}$ amber glass bottles that had been cleaned and baked at 450 degrees centigrade $\left({ }^{\circ} \mathrm{C}\right)$ by vendors approved by the NWQL. Water samples for DOC analysis were filtered using a 0.45 -micron pore-size capsule filter, preserved with $4.5 \mathrm{~N}$ sulfuric acid, and stored on ice until shipped to the NWQL in Denver, Colorado.

Samples for isotopes were collected according to methods described by the U.S. Geological Survey Reston Stable Isotope Laboratory (U.S. Geological Survey, 2008, 2009a). Samples for the analyses of stable isotopes of deuterium and oxygen were collected in $60-\mathrm{ml}$ clear glass bottles, filled to the top with no head space with unfiltered water, and sealed with a conical cap to prevent leakage and evaporation. Samples for carbon isotopes $\left({ }^{13} \mathrm{C}\right.$ and $\left.{ }^{12} \mathrm{C}\right)$ were collected in 1-liter glass bottles. Filtered sample water was allowed to overflow into the bottle, which was then capped with a polyseal cap to prevent evaporation, leakage, and introduction of ambient air into the sample. Unfiltered water sampled for isotopes of uranium ${ }^{238} \mathrm{U}$ and ${ }^{234} \mathrm{U}$ ) was collected in 1-liter acid-rinsed polyethylene bottles and acidified to a $\mathrm{pH}$ less than 2 with $7.7 \mathrm{~N}$ ultrex nitric acid. Samples for analysis of strontium isotopes $\left({ }^{87} \mathrm{Sr}\right.$ and $\left.{ }^{86} \mathrm{Sr}\right)$ were filtered into 1-liter polyethylene bottles and left unpreserved. Samples for isotopes of oxygen, deuterium, uranium, and strontium analyses were stored at ambient temperature and those for carbon were kept at $4{ }^{\circ} \mathrm{C}$ until shipment to the YMPL in Denver, Colorado for analysis.
The method used to collect dissolved gases and CFC samples followed procedures described by the U.S. Geological Survey (2009b), which allowed for easier collection of samples and for longer storage times; storage time was limited to about 6 months. After field measurements stabilized and just prior to collecting the sample, a clean 4-liter capacity beaker was filled with sample water. A $125-\mathrm{ml}$ glass bottle was then rinsed with sample water and lowered into the beaker where sample water was allowed to completely fill the bottle. Refrigeration-grade copper tubing, attached to the sample line at one end, was placed at the bottom of the glass bottle and at least 2 liters of sample water discharging from the copper tubing was allowed to flow from the bottom of the glass bottle into the filled beaker, allowing the beaker to overflow. After the 2-liter purge, the copper tubing was carefully removed from the bottle. While keeping the bottle submerged under water in the beaker to ensure no contact with air, the sample bottle was securely fitted with an aluminum-lined cap and then removed from the beaker, inverted, and checked for bubbles. When it was confirmed that there were no bubbles present in the sample, the bottle was dried and the cap secured with two rounds of electrical tape. Five bottles were collected at each sampling location. Each taped bottle was labeled with the sequence of sampling, inverted, and stored upside down on ice until shipped to the USGS Reston Chlorofluorocarbon Laboratory for analyses of dissolved gases and CFCs. All samples for dissolved gases and CFCs were collected in duplicate.

\section{Analysis of Water Samples}

All water samples were analyzed by USGS laboratories using standard analytical procedures and accepted quality assurance protocols. Samples were analyzed by the USGS NWQL for concentrations of DOC and nutrients (Brenton and Arnett, 1993; Fishman, 1993). Stable isotope sampling procedures largely followed those described by the USGS Reston Stable Isotope Laboratory (U.S. Geological Survey, 2008); however, the YMPL analyzed the samples for stable isotopes. All analyses followed National Research Council (NRC) and Department of Energy (DOE) quality assurance protocols (Brian Marshall, 2008, U.S. Geological Survey, written commun.). Concentrations of the same major constituent or isotope from individual sampling sites were considered different between sites if the relative difference between the concentrations exceeded what was considered to be within analytical acceptable limits.

Samples were not analyzed for dissolved-solids concentration as part of this study; however, because data were available for the major ions and alkalinity, a summation of selected major-ion concentrations was used as a surrogate for dissolved-solids concentration (Fishman and Friedman, 1985). Concentrations of calcium, carbonate, chloride, magnesium, nitrate, potassium, silicon dioxide, sodium, and sulfate were summed using milliequivalents of each constituent, generating a sum-of-constituents representing a dissolved-solids value for each site (Hem, 1992). 
Water samples were analyzed for major ions (calcium, chloride, fluoride, magnesium, potassium, silicon dioxide, sodium, sulfate), selected trace elements, and isotopes by the YMPL using standard operating procedures described in a series of YMPL in-house documents (Jim Paces, 2011, U.S. Geological Survey, written commun.) that are briefly described below.

Major ions were analyzed using ion chromatography, following the U.S. Environmental Protection Agency method of analysis for inorganic anions by ion chromatography and appropriate manufacturer specifications for the exchange column in use (O'Dell and others, 1984; Jim Paces, 2011, U.S. Geological Survey, written commun.). Standard reference waters (SRWs) and solutions were used to ensure accuracy of the analyses within plus or minus 20 percent with respect to bicarbonate. Trace elements were analyzed using inductively coupled plasma-mass spectrometry (ICP-MS). Standard reference materials (SRMs) obtained from the National Institute of Standards and Technology (NIST) were used to evaluate the accuracy of the ICP-MS analyses. For each trace element evaluated, ICP-MS analyses within plus or minus 20 percent of the NIST SRM analyzed at the same time as the environmental samples were considered to be within acceptable analytical limits.

Stable isotopes are nonradioactive forms of the same element having the same number of protons but a different number of neutrons. Reporting of isotopic data follows conventions adopted by the International Union of Pure and Applied Chemistry (IUPAC). The conventions recommend that isotopic data be expressed in reference to accepted reference materials (Coplen, 2011). Isotope values are presented in delta $(\delta)$ notation, which defines the amount of the rarer isotope to the more common isotope relative to a standard reference material (Clark and Fritz, 1997). These reference materials are Vienna Standard Mean Ocean Water (VSMOW) for $\delta \mathrm{D}$ and $\delta^{18} \mathrm{O}$ in water samples and in some cases $\delta^{18} \mathrm{O}$ in geologic materials. Generally, $\delta^{13} \mathrm{C}$ and $\delta^{18} \mathrm{O}$ isotope values from geologic samples are determined by using a calcite (marble) reference material (NBS-19) referred to as the Vienna Pee Dee Belemnite (VPDB; Clark and Fritz, 1997; Coplen, 2011). For example, $\delta^{18} \mathrm{O}$ represents the ratio ${ }^{18} \mathrm{O} /{ }^{16} \mathrm{O}$ relative to the Vienna Standard Mean Ocean Water (VSMOW) reference material. It is common practice to refer to water with negative $\delta^{18} \mathrm{O}$ and $\delta \mathrm{D}$ values to be "light" relative to values that have a more positive character; a $\delta^{18} \mathrm{O}$ value of -15 is considered lighter (or depleted in ${ }^{18} \mathrm{O}$ ) relative to a sample with a $\delta^{18} \mathrm{O}$ value of -12 . Delta values near zero indicate that the isotope values from the sample and reference material are similar.

Samples analyzed for the isotopes deuterium $\left({ }^{2} \mathrm{H}\right)$ and protium $\left({ }^{1} \mathrm{H}\right)$ were extracted from water samples using either a uranium or zinc shot method prior to analysis by mass spectrometry. In both methods, the water sample is heated in order to release hydrogen gas from the hydrogen atoms associated with the water molecule. The mass spectrometer used for the determination of the hydrogen isotopes is time-of-flight, whereby ions are separated based on the differences in their mass to charge ratios and characteristic velocities within the instrument. Samples of reference standards (VSMOW and Vienna Standard Light Antarctic Precipitation (VSLAP)) were analyzed before, during, and after the environmental samples. The VSMOW and VSLAP are standards used to evaluate ocean-derived water from water more depleted in ${ }^{18} \mathrm{O}$ and deuterium, respectively (Clark and Fritz, 1997). Adjustments to the deuterium and protium isotope data were made with respect to NIST-accepted values for VSMOW and VSLAP standards and the adjusted data reported. About 5 percent of the samples were analyzed in duplicate, and results of the duplicate analyses are required to be within 3 permil to be considered analytically acceptable.

Water samples being evaluated for oxygen isotopic composition are equilibrated with carbon dioxide of a known composition of ${ }^{18} \mathrm{O}$ and ${ }^{16} \mathrm{O}$ isotopes at $25^{\circ} \mathrm{C}$ for 48 hours. The amount of ${ }^{18} \mathrm{O}$ in the water sample is then determined by extracting the carbon dioxide from the water after equilibration and analyzing it using mass spectrometry. The ${ }^{18} \mathrm{O}$ in the water sample is then determined by the fractionation factor for oxygen isotopes between the carbon dioxide and water at $25^{\circ} \mathrm{C}$. Similar to the analysis of hydrogen isotopes, the data obtained from the analysis of ${ }^{18} \mathrm{O}$ is referenced to VSMOW and VSLAP standards, where the value of $\delta^{18} \mathrm{O}$ for samples of VSMOW is 0 permil and VSLAP is exactly -55.5 permil (Coplen, 2011). About 5 to 15 percent of the samples were analyzed in duplicate and measurement accuracy was generally within 0.4 permil.

Water samples collected for analysis of strontium isotope $\left({ }^{87} \mathrm{Sr}\right.$ and ${ }^{86} \mathrm{Sr}$ ) composition were evaporated to dryness followed by resuspension of the dried solid using nitric acid. After resuspension, the mixture was centrifuged to separate the acid supernatant from the solid material and the strontium isolated from the acid solution using an ion-exchange resin. Thermal ionization mass spectrometry was used to determine the strontium isotope ratio, ${ }^{87} \mathrm{Sr} /{ }^{86} \mathrm{Sr}$, within 0.0001 permil.

To analyze for the carbon isotopes ${ }^{13} \mathrm{C}$ and ${ }^{12} \mathrm{C}$, carbon dioxide was extracted from the water using phosphoric acid and cold trapping. The carbon dioxide was subsequently analyzed using mass spectrometry. The standard reference material used for the determination of ${ }^{13} \mathrm{C}$ and ${ }^{12} \mathrm{C}$ was TS-1, a crushed marble similar to NBS-19. Standard reference material measurements within 0.1 permil and duplicate analytical measurements of ${ }^{13} \mathrm{C}$ in environmental samples within plus or minus 0.2 permil were considered within acceptable analytical limits.

To determine the relative amounts of uranium isotopes ${ }^{238} \mathrm{U}$ and $\left.{ }^{234} \mathrm{U}\right)$ in water samples, samples were evaporated to dryness and treated in sequence with nitric acid and, after drying a second time, resuspended in hydrogen bromide. The hydrogen bromide solution was then further prepared for thermalionization mass spectrometry by using ion-exchange chromatography. NIST SRM material was used to evaluate analytical performance where all measurements, if considered acceptable, were within 2 percent of the certified value. 


\section{Collection of Rock Samples}

Four fresh rock samples were collected using a rock hammer from outcrops in the vicinity of selected caves and springs: two samples of the Pole Canyon Limestone in the Baker Creek drainage (sites 6,7), and one sample of carbonate rock each in the vicinity of Squirrel Cave and Outhouse Spring in the Snake Creek drainage (sites 14, 15; fig. 2; table 1).

\section{Analysis of Rock Samples}

Four samples representative of the three major carbonate formations (Pole Canyon Limestone, Fish Haven/Laketown dolomites, and Pogonip Group Limestone) in the study area were collected and analyzed for selected elements and isotopes of carbon, oxygen, and strontium by the YMPL in Denver, Colorado. Analytical procedures, summarized in the following paragraphs, were provided by Jim Paces (2011, U.S. Geological Survey, written commun.). Rock samples were pulverized to a 200 mesh size, as appropriate, before further processing for analysis.

Isotopes of carbon $\left({ }^{13} \mathrm{C}\right.$ and $\left.{ }^{12} \mathrm{C}\right)$ and oxygen $\left({ }^{18} \mathrm{O}\right.$ and $\left.{ }^{16} \mathrm{O}\right)$ were evaluated in carbonate rocks by evolving carbon dioxide from powdered rock samples using phosphoric acid. The carbon dioxide was trapped and analyzed for isotopic composition using mass spectrometry in the same manner as analyzed in water samples, described previously. Measurement accuracy is within plus or minus 0.1 permil. All analyses were made in replicate and acceptable results were considered to be within plus or minus 0.2 permil.

Pulverized carbonate rocks were dissolved in weak aqua regia (a combination of hydrochloric and nitric acids). After extraction and bringing the extraction slurry to dryness, the solid residue was resuspended using nitric acid. After separating the acid supernatant from the solid residue remaining after resuspension, an ion-exchange resin was used to separate the strontium from the acidic supernatant. Thermal ionization mass spectrometry was used to determine the strontium isotope ratio, ${ }^{87} \mathrm{Sr} /{ }^{86} \mathrm{Sr}$, in permil. The error associated with reported values of ${ }^{87} \mathrm{Sr} /{ }^{86} \mathrm{Sr}$ was plus or minus 0.00003 permil at the 95-percent confidence level.

\section{Quality Assurance}

Instruments used to measure field parameters ( $\mathrm{pH}$, specific conductance, and alkalinity) are evaluated on an annual basis as part of the National Field Quality Assurance (NFQA) Program. As part of the NFQA process, laboratory prepared samples for the analysis of $\mathrm{pH}$, specific conductance, and alkalinity are sent to USGS offices throughout the country for measurement by trained USGS personnel tasked with collection of these types of data in the field. Equipment that does not meet acceptable performance criteria are serviced or replaced as needed. Thermisters are checked for accuracy against NIST calibrated thermometers.
As an additional measure of quality assurance evaluating possible contamination due to sampling equipment and cleaning procedures, an equipment blank was processed using the same equipment used for processing environmental samples. For the purposes of this study, the equipment blank was analyzed for inorganic constituents (nutrients, major ions, and trace elements) using inorganic-grade deionized water that was purchased from an approved source where certificates of analysis are available (Mueller and others, 1997). The information from the certificate of analysis is summarized in appendix 1 (table 1-1).

\section{Recharge Altitude}

The temperature dependent solubility of dissolved noble gases into water and their relatively conservative behavior makes these gases useful in evaluating groundwater recharge temperatures, which in turn, can be used to estimate the altitude at which meteoric water entered the water table as recharge. In addition to noble gases such as argon (Ar), other gases including carbon dioxide, nitrogen, and oxygen dissolve in water as it passes through the atmosphere as precipitation and as it percolates through the unsaturated zone before becoming groundwater (Stute and Schlosser, 2001). The amount of dissolution depends on temperature, pressure, and salinity of the water as it moves through the system (Aeschbach-Hertig and others, 1999). The advantage of evaluating noble gases is that they are chemically inert (unreactive) and their concentrations are fairly constant from points of recharge to discharge (Manning, 2008). If the groundwater environment is sufficiently oxidizing (dissolved-oxygen concentrations greater than $0.5 \mathrm{mg} / \mathrm{L}$ ) whereby denitrification is not likely to be occurring, diatomic nitrogen $\left(\mathrm{N}_{2}\right)$ can be considered to behave conservatively and also can be used to evaluate the altitude of recharge.

A complicating factor associated with using dissolved gases to estimate recharge temperatures and altitude is the presence of dissolved gases in the groundwater system at higher concentrations than expected when in equilibrium with the atmosphere, called "excess air" (Kipfer and others, 2002; Manning, 2008). Volumes of excess air were calculated using a back solving routine by iteration at $500-\mathrm{ft}$ increments of assumed recharge altitude until the calculated excess air volumes were the same as when calculated using concentrations of $\mathrm{Ar}$ and $\mathrm{N}_{2}$ (U.S. Geological Survey, 2009b).

Ranges in recharge temperature and altitude were determined using the same back solving routine based on the temperature dependent solubilities for $\mathrm{Ar}$ and $\mathrm{N}_{2}$ by iteration, as described above (U.S. Geological Survey, 2009b). An atmospheric temperature lapse rate is the change in temperature over a specified change in altitude. Temperature boundary conditions used to assess whether or not the values computed from the back solving routine were reasonable were a minimum temperature associated with melting ice $\left(0.5^{\circ} \mathrm{C}\right)$ and a maximum possible temperature based on lapse rates 
determined by Prudic and Glancy (2009). Prudic and Glancy (2009) calculated a decrease in temperature of $2{ }^{\circ} \mathrm{C}$ for every 1,000 -ft increase in altitude within the Lehman Creek drainage near the Lehman Caves Visitor Center within the park. The estimated recharge temperatures calculated using this rate were evaluated against temperatures derived using the rate obtained from Hershey and others (2007) of $2.1{ }^{\circ} \mathrm{C}$ for every $1,000-\mathrm{ft}$ rise in altitude. The decrease in air temperatures per $1000-\mathrm{ft}$ rise in altitude determined by Hershey and others (2007) and Prudic and Glancy (2009) were evaluated relative to the temperature and altitude of an appropriate reference point near the study area. The reference point used for this study was the Great Basin National Park Climate Station situated at $6,830 \mathrm{ft}$ above sea level, with an average annual temperature of $9{ }^{\circ} \mathrm{C}$, calculated as the average between the annual average minimum $\left(2.0^{\circ} \mathrm{C}\right)$ and maximum $\left(15.9^{\circ} \mathrm{C}\right)$ temperatures (Western Regional Climate Center, 2011). A linear relationship was used to evaluate the maximum estimated recharge temperature with respect to a decrease in temperature per $\mathrm{ft}(\mathrm{LR})$ in altitude of -0.002 and $-0.0021{ }^{\circ} \mathrm{C} / \mathrm{ft}$ determined by the two studies, respectively. The relationship is shown by

$$
\mathrm{T}_{2}=\mathrm{T}_{1}+(\mathrm{LR}) *\left(\mathrm{Z}_{2}-\mathrm{Z}_{1}\right)
$$

where

$$
\begin{gathered}
\mathrm{T}_{2} \quad \begin{array}{c}
\text { is the estimated recharge temperature associated } \\
\text { with the assumed recharge altitude } \\
\text { represents the assumed recharge altitude, } \\
\text { evaluated at } 500 \text {-ft increments, and } \\
\mathrm{Z}_{1} \text { and } \mathrm{T}_{1}
\end{array} \\
\begin{array}{c}
\text { represent the altitude and the average annual } \\
\text { temperature at the Great Basin National Park } \\
\text { Climate Station, respectively. }
\end{array}
\end{gathered}
$$

All recharge associated with streams, springs, and standing pools of water in caves was assumed to occur at altitudes above the sampling site. The minimum altitude evaluated $(6,500 \mathrm{ft})$ was constrained by the lowest altitude sampling site included in this study (6,200 ft; Spring Creek Spring). For each site a minimum and maximum recharge altitude was determined.

\section{Residence Time}

Residence time represents the time that water takes from when it enters the subterranean environment as recharge to the point where it discharges. Residence time was determined on the basis of the relation between CFC-11, CFC-12, and CFC-113 concentrations in samples collected from springs and caves in the study area to known amounts of these CFCs in the atmosphere and calculated mixing ratios of the various CFCs in the air, which have been characterized over time (Plummer and Busenberg, 2011). Groundwater ages calculated on the basis of CFC analyses are more appropriately termed "apparent age" as there are geochemical considerations not taken into account when using these compounds as age-dating tools such as adsorption and microbial degradation (Plummer and Busenberg, 2011). Other factors such as seasonal fluctuations in atmospheric transport patterns, thickness of unsaturated zones, soil porosity, and gas diffusion coefficients also influence CFC concentrations found in groundwater. Using CFCs to date groundwater assumes that concentrations of CFCs in air last in contact with the water (atmospheric or soil-gas) remain essentially the same from the point where the water enters the water table to where it discharges. This study assumes piston flow, where a given volume of groundwater is traveling along a flow path under closed conditions.

Because the concentrations of gases in water are dependent on the ability (or inability) of a gas to escape the aqueous environment through volatilization, this ability to volatilize from water needs to be characterized. To that end, compoundspecific constants (termed Henry's law constants) have been experimentally derived and are available in the scientific literature for volatile (gaseous) substances such as CFCs. A Henry's Law constant is the ratio of the concentration of a compound in the gas phase (air) to that in the aqueous phase which is influenced by the salinity and temperature of the water and the temperature and pressure of the atmosphere above the water (Schwartzenbach and others, 1993). The calculation of groundwater age based on CFC-11, CFC-12, and CFC-113 concentrations is derived based on the Henry's Law constants for these CFCs (Plummer and Busenberg, 2011). Temperature and pressure at the point of recharge are important considerations that need to be included when evaluating CFC concentrations in aqueous systems (Plummer and Busenberg, 2011). Higher altitudes have lower atmospheric pressure and temperatures than lower altitudes. The estimated recharge altitudes and temperatures characterized using dissolved gases as described in the previous section were used in the calculation of apparent groundwater age based on CFC concentrations. Generally, CFCs are an effective way of dating groundwaters within a 50-year time scale (Plummer and Busenberg, 2011).

\section{General Water Chemistry of Selected Streams, Springs, and Caves}

An evaluation of general water chemistry characteristics included a comparison of dissolved oxygen, specific conductance, alkalinity, and concentrations of major ions and trace elements among water samples collected from selected streams, springs, and caves in each of the upper Baker and Snake Creek drainages (appendix 2, table 2-1). Results of isotopic analyses for carbon $\left(\delta^{13} \mathrm{C}\right)$, deuterium $(\delta \mathrm{D})$, oxygen $\left(\delta^{18} \mathrm{O}\right)$, strontium $\left({ }^{87} \mathrm{Sr} /{ }^{86} \mathrm{Sr}\right)$, and uranium $\left({ }^{324} \mathrm{U} /{ }^{238} \mathrm{U}\right)$ were used to further refine preliminary relations among the water samples and, in some cases, geologic formations.

Geologic datasets were available for Great Basin National Park and several rock samples were collected from selected outcrops representing the limestone (Pole Canyon and Pogonip) and dolomites (Fish Haven/Laketown) near the caves and 
springs sampled in the drainages and analyzed for selected elemental (appendix 2, table 2-2) and isotopic composition. Additional chemical and isotopic composition of rocks in the study area were obtained from previous investigations (Lee and others, 1986; Prudic and Glancy, 2009). Measurements of alkalinity and relative concentrations of bicarbonate, calcium, and magnesium in water were used to examine possible, and relative, interactions with carbonate rocks.

Dissolved gas (argon, carbon dioxide, methane, and nitrogen) data were used to approximate possible recharge altitudes, temperature, and excess air concentrations for groundwater discharging from selected springs and into selected caves. CFC concentrations, which are influenced by pressure, temperature, and excess air concentrations, were used to estimate apparent groundwater residence times. The integration of general chemical characteristics, isotopic data, knowledge of available geologic features, and age-dating techniques all contributed to this preliminary assessment of the water chemistry of selected streams, springs, and caves in the upper Baker and Snake Creek drainages.

\section{Deuterium and 0xygen-18}

The source of water recharging aquifers in Spring and Snake Valleys is from the mountains surrounding these valleys, including the Snake Range (Halford and Plume, 2011). Values of $\delta \mathrm{D}$ and $\delta^{18} \mathrm{O}$ were compared to the global meteoric water line (Craig, 1961) in order to evaluate the type of precipitation primarily responsible for recharging the water observed discharging from springs and to caves within the upper Baker and Snake Creek drainages in the park. Using data from Acheampong (1992) and Friedman and others (2002), an estimated local meteoric water line was generated for the general area in and near Great Basin National Park (fig. 4).

Isotopically light values (more negative) are associated with winter precipitation (snow) and isotopically heavy values (less negative) are associated with warmer summer rain events (Prudic and Glancy, 2009). Groundwater originates from precipitation as rain or snow. In either case, a certain percentage of the precipitation will evaporate from the land surface and the remaining will either run off into nearby streams or percolate through cracks in rocks or infiltrate through soils eventually becoming groundwater. Results of isotopic analyses for $\delta \mathrm{D}$ and $\delta^{18} \mathrm{O}$ indicate that the majority of the samples collected as part of this study fall within the isotopic window indicative of winter precipitation in the area (fig. $4 A$ ). Although climatic conditions, such as humidity, can influence the way isotopes partition as a result of evaporation, generally during evaporation, lighter isotopes $\left({ }^{1} \mathrm{H}\right.$ and $\left.{ }^{16} \mathrm{O}\right)$ are released into the atmosphere before the heavier isotopes $\left(\mathrm{D}\right.$ and ${ }^{18} \mathrm{O}$; Clarke and Fritz, 1999). Given that the isotopic composition of the sample waters reside near the volumetric weighted mean, on the heavier side of the winter precipitation range, some of these waters are likely a mixture of primarily winter precipitation with a lesser amount of summer precipitation. Although some of the sample values deviate from the meteoric lines, the deviation is still within the data indicative of local precipitation (fig. 4B). It appears as though evaporation has had little influence on the water chemistry of samples collected as part of this study.

\section{General Water Chemistry and Geologic Characteristics}

A comparison of alkalinity, specific conductance, $\mathrm{pH}$, and concentrations of major-ion and trace-elements in water samples shows that differences exist among selected streams, springs, and caves included in this investigation (appendix 2, table 2-1). Initially, in many cases, the data suggest that these differences may have arisen from the geologic environments through which the water came into contact before discharging to the surface from a spring or into a cave.

The source of dissolved solids largely comes from the interaction of water with rock (Hem, 1992). Some of the factors influencing the chemical nature of water resulting from its interaction with rocks include rock composition, crystal size and presence or absence of impurities, texture and porosity, and the amount of time water is in contact with the rocks. Generally, strong relations are found between dissolved solids and specific conductance where waters are not too dilute or saline (Hem, 1992). Using the sum-of-constituents as a surrogate for dissolved solids, there is a strong relation between specific conductance and the sum-of-constituents (fig. 5). Using Spearman correlation analysis, at a significance level of 0.05 , the constituents that had the greatest correlation to specific conductance were bicarbonate $(\mathrm{rho}=0.973)$, magnesium $($ rho $=0.973)$, calcium $($ rho $=0.955)$, sulfate $($ rho $=0.891)$, sodium $($ rho $=0.873)$, and chloride $(r h o=0.836)$. The remaining constituents used to calculate the sum-of-constituents (nitrate, potassium, and silicon dioxide) had Spearman rho correlations that ranged from 0.416 to 0.618 with significance levels ranging from 0.04 to 0.19 . Bicarbonate, calcium, and magnesium had the strongest correlations to specific conductance and were strongly correlated with each other $(0.936 \leq$ rho $\leq 0.991 ; p<0.05)$. The calcium and magnesium originate from carbonate rocks (limestone and dolomite) in the area as a relation between these elements and alkalinity can be shown (fig. 6). In all cases, concentrations of calcium were higher than magnesium.

Water samples collected from springs and caves with relatively low specific conductance likely represent conditions where source water has rapidly flowed through the system and(or) minimal dissolution of rock substrates occurred while water was in contact with the rock (Prudic and Glancy, 2009). Water samples collected from Baker Creek (site 1), Model Cave (site 4), and Rosethorn Spring (site 5) in the upper Baker Creek drainage and the sample collected from Snake Creek at the pipeline outlet (site 9) in the upper Snake Creek drainage plot on the lower end of the relation between the sum-ofconstituents and specific conductance (specific conductance 

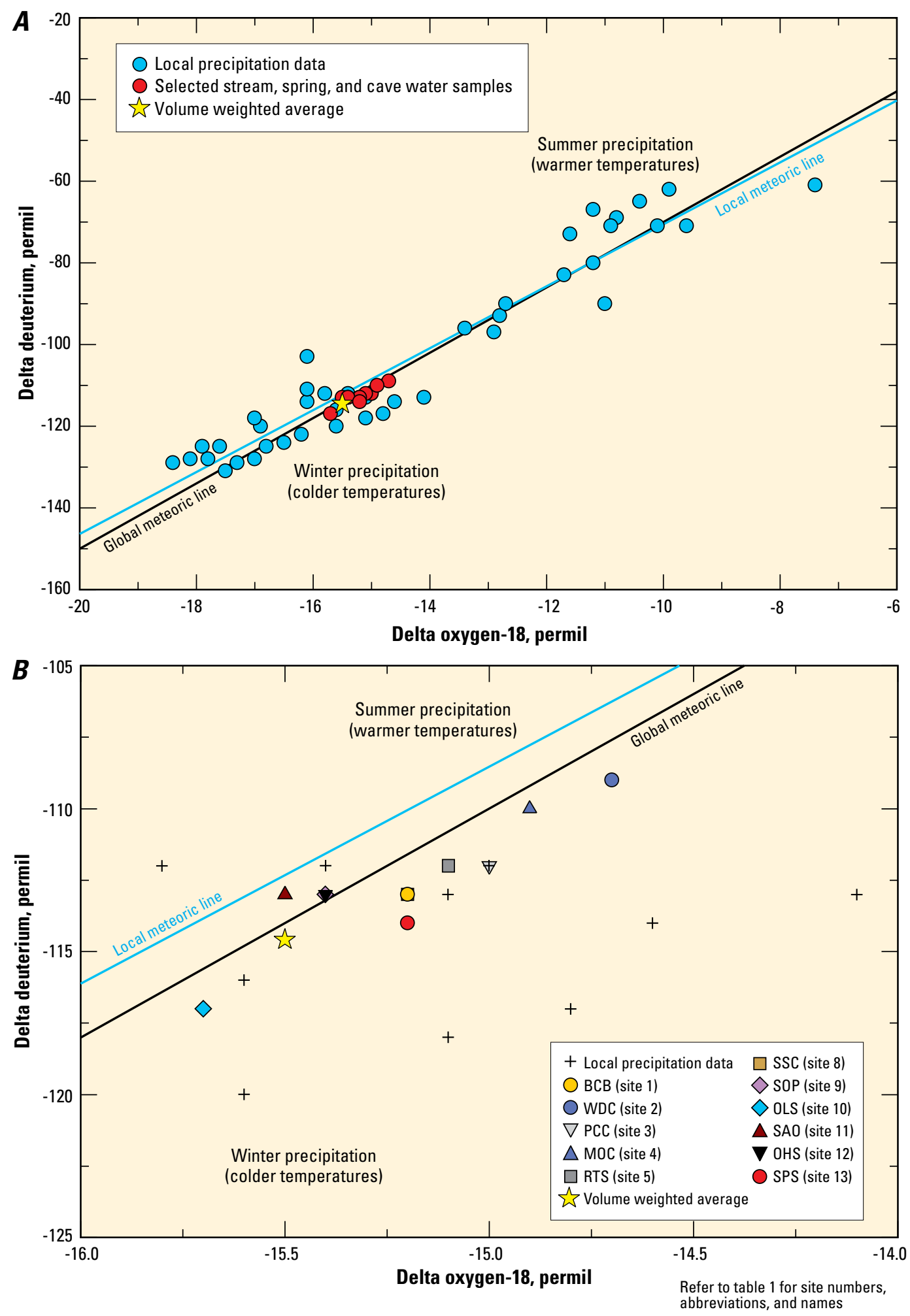

Figure 4. Delta deuterium and delta oxygen-18 values in $A$, local precipitation and water samples collected from selected streams, springs, and caves in the upper Baker and Snake Creek drainages in Great Basin National Park, Nevada, February 2009, and B, expanded view of water samples in relation to the local and global meteoric water lines. 


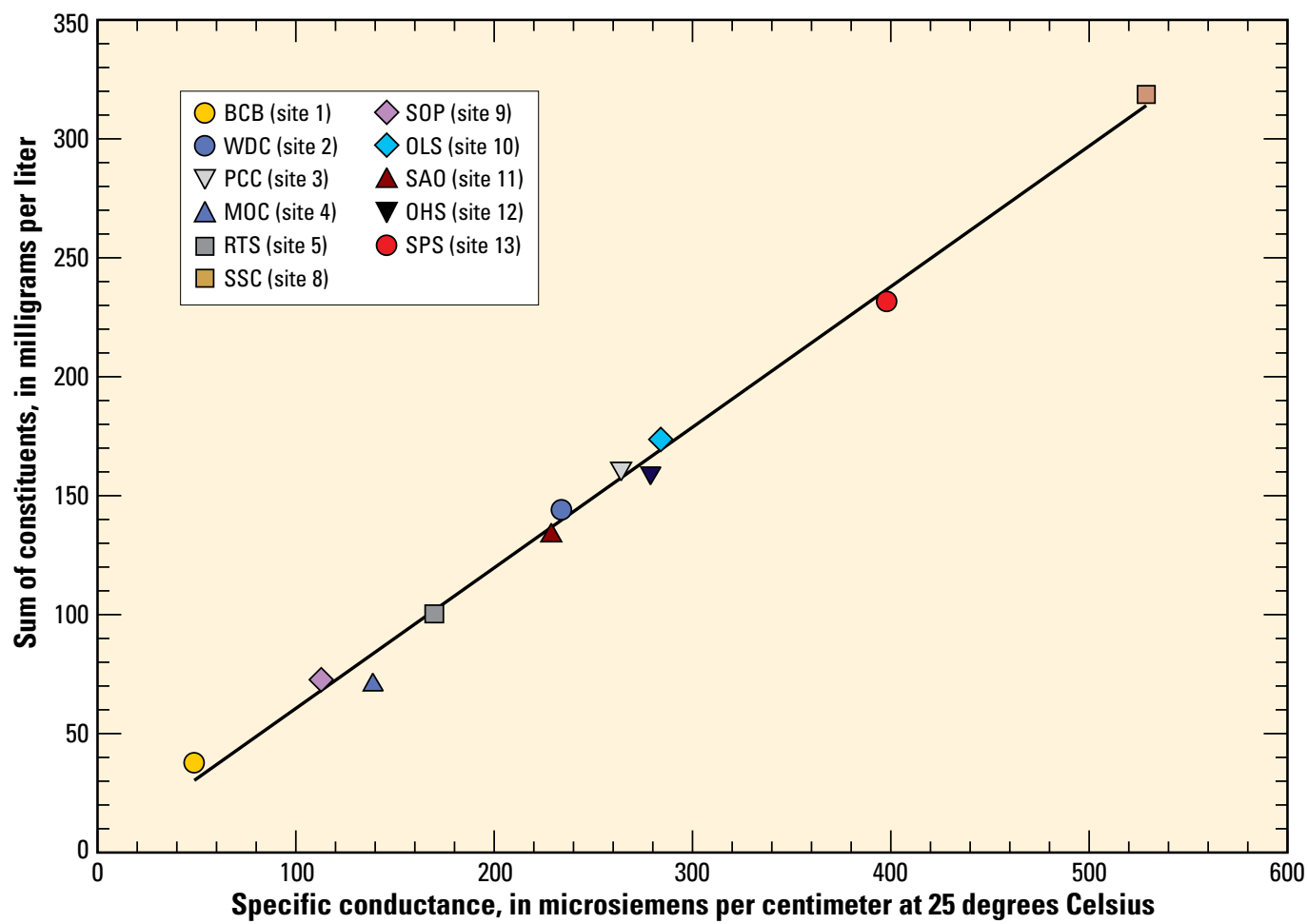

Figure 5. Relation between specific conductance and sum-of-constituents in water samples collected from selected streams, springs, and caves in the upper Baker and Snake Creek drainages in Great Basin National Park, Nevada, February 2009.

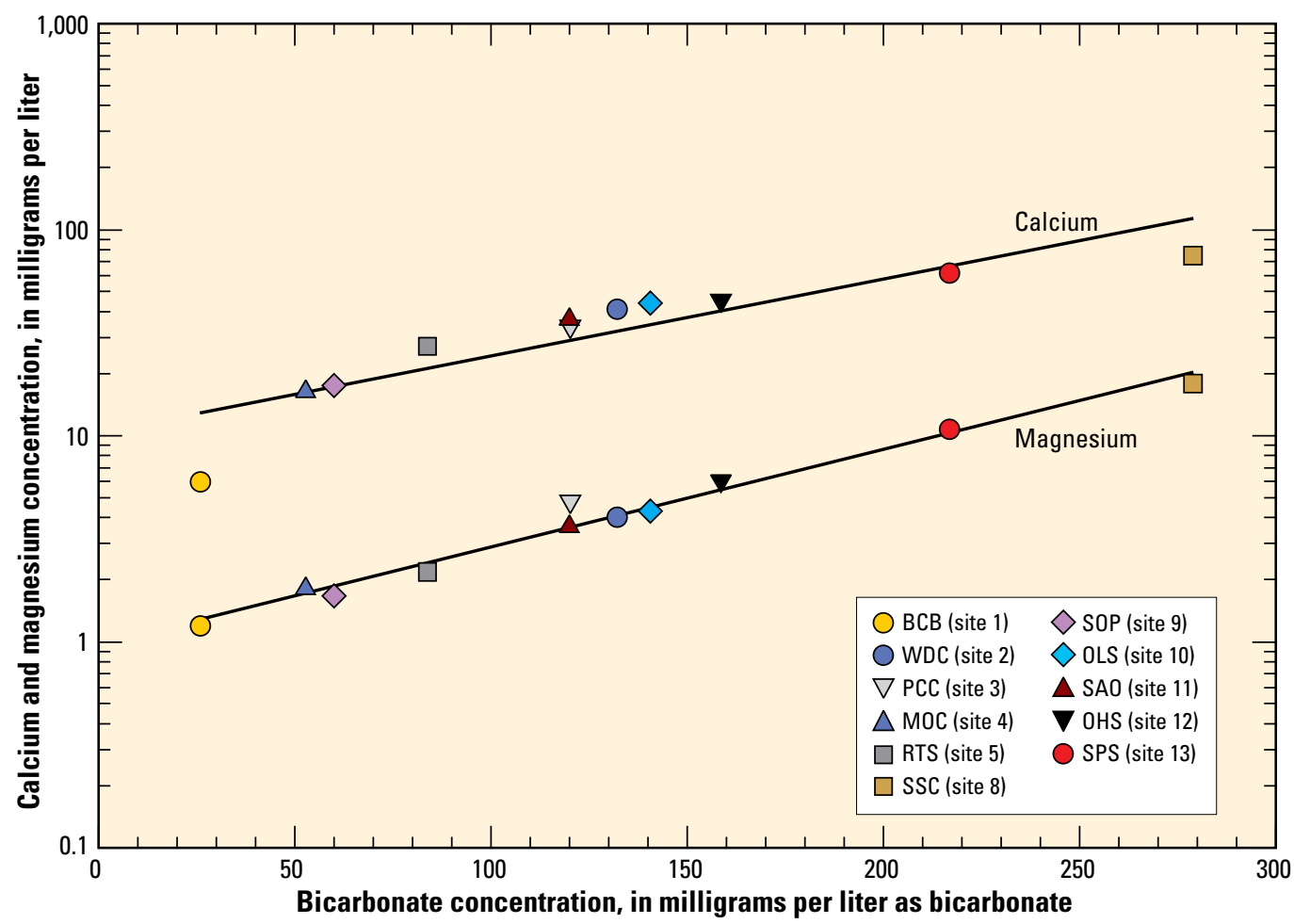

Figure 6. Relation between calcium and magnesium to bicarbonate concentrations in water samples collected from selected streams, springs, and caves in the upper Baker and Snake Creek drainages in Great Basin National Park, February 2009. 
values lower than $200 \mu \mathrm{S} / \mathrm{cm}$ at $25^{\circ} \mathrm{C}$; sum-of-constituents less than $110 \mathrm{mg} / \mathrm{L}$; fig. 5). The highest specific conductance and sum-of-constituents values were found in water collected from Squirrel Spring Cave (site 8) and Spring Creek Spring (site 13) in the upper Snake Creek drainage; these sites represent both the most upgradient and downgradient sites in the upper Snake Creek drainage, respectively. These results indicate varying influences on water chemistry that could be due to one or more of the following: (1) the relative position of the sample along a flow path, (2) fast infiltration and flow rates in areas where water samples had relatively low sum-of-constituents and specific conductance, (3) differences in geologic formations through which the water came into contact, or (4) conditions reflecting mixing waters. Rocks that are readily soluble, such as carbonates, can contribute more to water chemistry than less soluble rocks, such as siliciclastics over the same time water was in contact with the rock.

Water samples collected from upper Baker and Snake Creeks, selected springs, and caves were characterized for general water type. Constituents used to determine the general water type (on the basis of relative concentrations in milliequivalents) were bicarbonate plus carbonate, calcium, chloride, magnesium, potassium, sodium, and sulfate (appendix 2, table 2-1). All water samples were characterized as calciumbicarbonate (fig. 7).

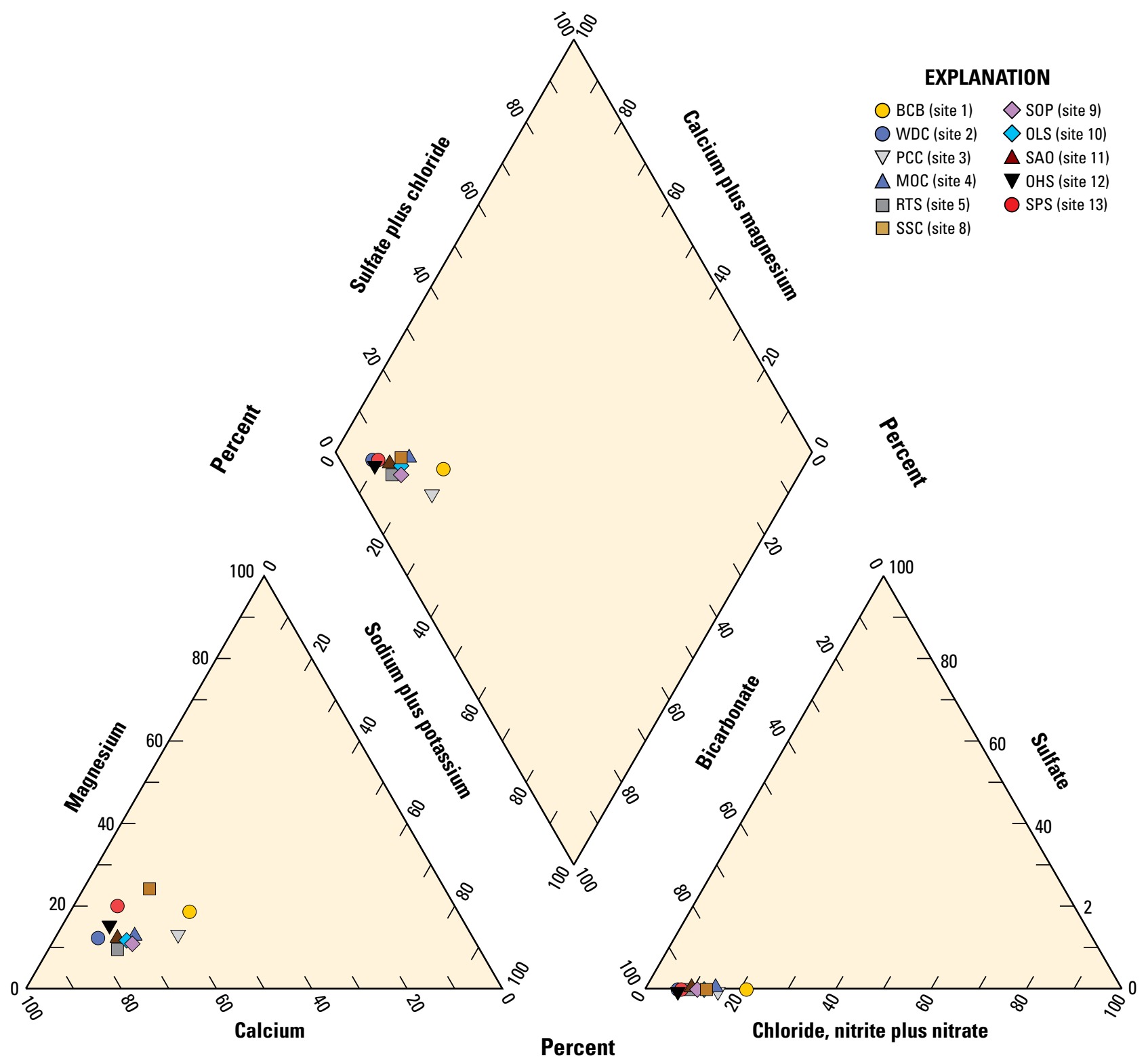

Figure 7. Distribution of general water-chemistry characteristics using selected major-ion concentrations in water samples collected from selected streams, springs, and caves in the upper Baker and Snake Creek drainages in Great Basin National Park, Nevada, February 2009. 


\section{Carbon Isotope $\left(\delta^{13} \mathrm{C} /{ }^{12} \mathrm{C}\right)$ Assessment}

The mass of carbon in groundwater depends on the sources of organic carbon, inorganic carbon, and plant activity at the surface (Clark and Fritz, 1997). Dissolved organic carbon concentrations ranged from 0.5 to $2.5 \mathrm{mg} / \mathrm{L}$ in the upper Baker Creek drainage and from 0.5 to 1.3 in the upper Snake Creek drainage (appendix 2, table 2-1). Dissolved inorganic carbon (DIC) originates from atmospheric carbon dioxide dissolved in the water at the time of recharge, additional carbon dioxide that is introduced into the water as it infiltrates through the soil zone, and the dissolution of carbonate rocks within an aquifer (Clark and Fritz, 1997). The 2007 mean annual average $\delta^{13} \mathrm{C}$ value determined from atmospheric carbon dioxide data collected from LaJolla, California (-8.320 permil) and Alert, Canada ( -8.358 permil) is -8.34 permil (Keeling and others, 2010 a,b). The 2007 data were used as these were the most recent $\delta^{13} \mathrm{C}$ data available. The form that inorganic carbon takes in groundwater is dependent on $\mathrm{pH}$. Generally, calcite dissolution is influenced by carbonic acid derived from the reservoir of carbon dioxide in the soil. Soils can have carbon dioxide concentrations, that are derived from the decomposition of organic matter by bacteria, that are up to 100 times that found in the atmosphere (Clark and Fritz, 1997). In soils supporting the most common types of plants $\left(\mathrm{C}_{3}\right.$ vegetation), the carbon dioxide $\delta^{13} \mathrm{C}$ signature is about -23 permil (Clark and Fritz, 1997). In open systems, typical of the unsaturated zone, the reservoir of carbon dioxide is essentially unlimited and calcite dissolution can readily take place (Clark and Fritz, 1997). In a closed system, recharge water infiltrates to the saturated zone before any significant dissolution of calcite can take place, and the groundwater is closed off to the carbon dioxide reservoir. Quartz and silicate rocks, such as granites, are not nearly as susceptible to dissolution reactions as carbonates and therefore, large changes in DIC characteristics do not result from water coming into contact with these materials (Clark and Fritz, 1997).
The isotopic composition of rocks develops during diagenesis and sedimentation (Clark and Fritz, 1997). Geologic isotope data are expressed in terms of a standard reference material used for geologic substances, VPDB, for both $\delta^{13} \mathrm{C}$ and $\delta^{18} \mathrm{O}$ isotopes. VPDB is derived from marine precipitated carbonate and, as a result, carbonates formed from marine water will take on an isotopic signature similar to the reference material, and the values reported will be near zero, plus or minus a few permil (Clark and Fritz, 1997). The Cordilleran geosyncline is an oceanic trough of late Precambrian to Mesozoic age where rocks were deposited along the western coast of North America that existed during that time (about 600 to 65 million years ago) and included the eastern side of the Great Basin (Hose and Blake, 1976; Stewart, 1980). Because the carbonates in the Great Basin were precipitated in a marine environment, the $\delta^{13} \mathrm{C}$ values are near zero values ( -3 to +0.5 permil; table 2 ). The values -23 permil (soil carbon dioxide $\delta^{13} \mathrm{C}$ signature) and those determined for Great Basin National Park carbonate samples were used in this study as the lower and upper $\delta^{13} \mathrm{C}$ limits (end members), respectively, for $\delta^{13} \mathrm{C}$ in water samples collected from the selected streams, springs, and caves in the upper Baker and Snake Creek drainages (fig. 8).

If water sampled during this study was only exposed to carbon originating from the dissolution of limestone and (or) dolomite, the values for the groundwater would all be similar to the near zero values ranging from -3 to 0.5 permil; however, the values of $\delta^{13} \mathrm{C}$ for water sampled from streams, springs, and caves ranged from -12.7 to -8.1 permil (table 3 ). Three water samples collected in the Lehman Creek drainage, north of the study area, and one in the Baker Creek drainage, had $\delta^{13} \mathrm{C}$ values ranging from -16.0 to -10.0 permil (Prudic and Glancy, 2009). The positive relation found between bicarbonate and $\delta^{13} \mathrm{C}$ values in samples collected from the Lehman Creek drainage was attributed to increasing amounts of bicarbonate from dissolution, causing an increase in $\delta^{13} \mathrm{C}$ values. It is likely that carbon dioxide dissolves into recharge water as it

Table 2. Carbon, oxygen, and strontium isotope ratios in rock samples collected near selected streams and caves in the upper Baker and Snake Creek drainages in Great Basin National Park, Nevada, February 2009.

[Abbreviations: permil, per thousand; VPDB, Vienna Pee Dee Belemnite; VSMOW, Vienna Standard Mean Ocean Water; g/kg, grams per kilogram]

\begin{tabular}{|c|c|c|c|c|c|}
\hline $\begin{array}{l}\text { Isotope value } \\
\text { (permil) }\end{array}$ & $\begin{array}{c}\text { Site } 6 \\
\text { Pole Canyon } \\
\text { Limestone }\end{array}$ & $\begin{array}{c}\text { Site } 7 \\
\text { Pole Canyon } \\
\text { Limestone }\end{array}$ & $\begin{array}{c}\text { Site } 14 \\
\text { Fish Haven/Lake- } \\
\text { town Dolomites }\end{array}$ & $\begin{array}{c}\text { Site } 15 \\
\text { Pogonip Group } \\
\text { Limestone }\end{array}$ & $\begin{array}{c}\text { Pole Canyon } \\
\text { Limestone }^{1}\end{array}$ \\
\hline Carbon-13/Carbon-12 $\left({ }^{13} \mathrm{C} /{ }^{12} \mathrm{C}\right)$ ratio, as $\delta^{13} \mathrm{C}_{\mathrm{VPDB}}$ & -0.1 & 0.5 & -0.2 & -3.0 & -0.82 \\
\hline Oxygen-18/Oxygen- $16\left({ }^{18} \mathrm{O} /{ }^{16} \mathrm{O}\right)$ ratio, as $\delta^{18} \mathrm{O}_{\text {vsmow }}$ & 15.3 & 12.7 & 22.4 & 22.4 & 2.04 \\
\hline Strontium-87/Strontium- $86\left({ }^{87} \mathrm{Sr} /{ }^{86} \mathrm{Sr}\right)$ ratio & 0.70986 & 0.70955 & 0.70927 & 0.70971 & 0.71358 \\
\hline Strontium concentration $(\mathrm{g} / \mathrm{kg})$ & 27.0 & 76.1 & 3.9 & 29.2 & 0.240 \\
\hline
\end{tabular}

${ }^{1}$ From Prudic and Glancy (2009, p. 18); the value for $\delta^{18} \mathrm{O}$ relative to VPDB (-28.0) was converted to the VSMOW standard and the converted value represented in this table. 


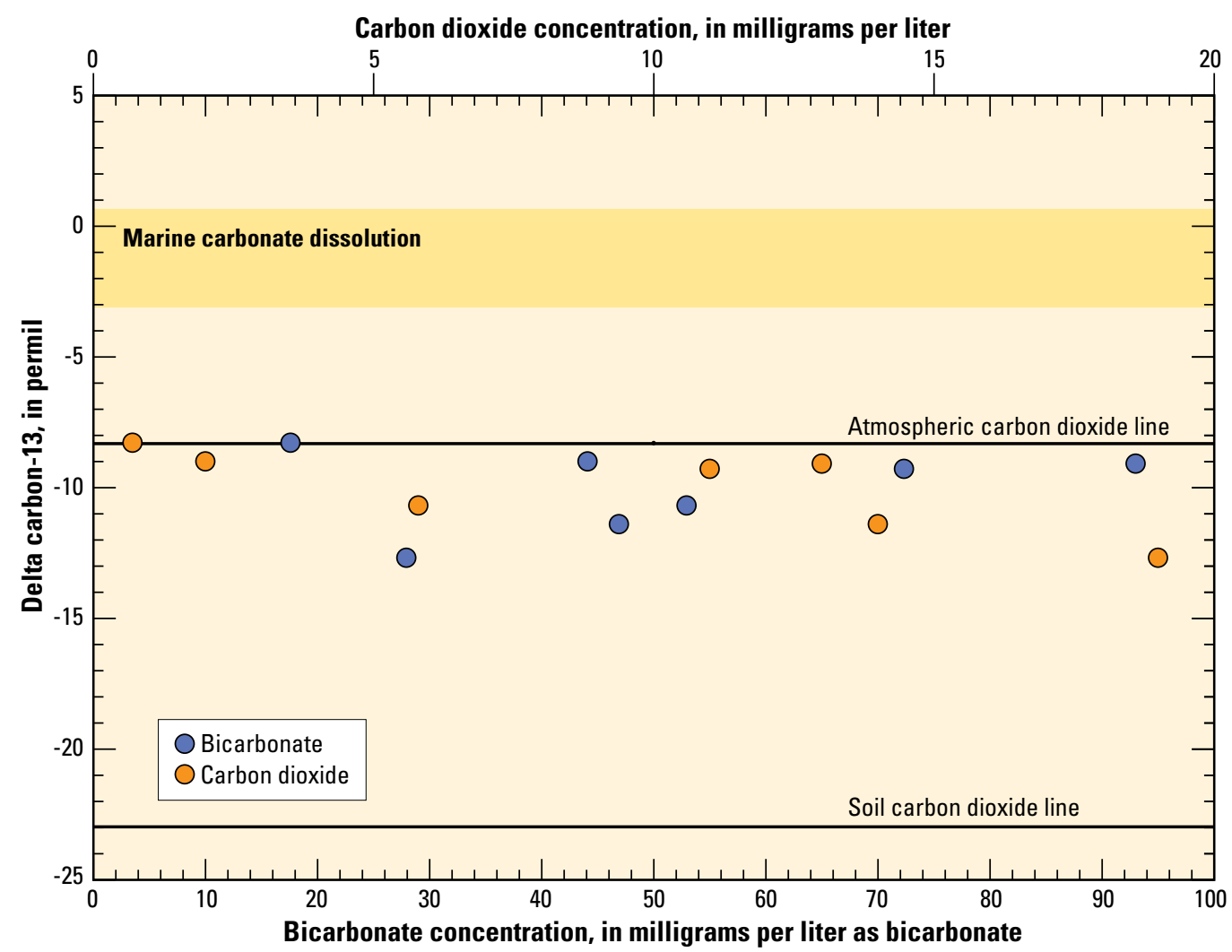

Figure 8. Relation between delta carbon-13 values and bicarbonate and carbon dioxide concentrations in water samples collected from selected streams, springs, and caves in the upper Baker and Snake Creek drainages in Great Basin National Park, Nevada, February 2009.

moves through the unsaturated soil zone. As this water flows through the carbonate terrain and dissolves the rock, the water takes on a $\delta^{13} \mathrm{C}$ signature falling between the two end members (unsaturated soil carbon dioxide and carbonate rock carbon, fig. 8).

The relation between DIC, in the form of bicarbonate, and calcium and magnesium in samples collected as part of this investigation indicates that dissolution of carbonate substrates is occurring and influencing the water chemistry at these sites. The carbon isotope data suggest a complex chemical interplay among various potential phenomena in the system. It is likely that varying infiltration rates, travel times, lithologies, and possibly the mixing of waters originating from different source areas are influencing the geochemical conditions reflected in each of the sample waters collected during this study. It may be possible that evapotranspiration occurring in areas upgradient from discharge areas may be influencing the $\delta^{13} \mathrm{C}$ values, as photosynthesis preferentially consumes ${ }^{12} \mathrm{C}\left(\mathrm{O}^{\prime}\right.$ Leary, 1988), which would result in increasing values of $\delta^{13} \mathrm{C}$ (Clark and Fritz, 1997).

\section{Upper Baker Creek Drainage}

Baker Creek: The water sample collected from Baker Creek (site 1) had characteristically low specific conductance, alkalinity, and concentrations of calcium and magnesium relative to the other stream samples collected as part of this study (appendix 2, table 2-1). The relatively low values of these parameters could be due to the introduction of water to the stream from springs associated with the glacial deposits that overlie quartzite, argillite, and shale in the headwaters of the drainage (Elliot and others, 2006; Prudic and Glancy, 2009). As there was only one sample collected from Baker Creek, measurements of general water chemistry characteristics and concentrations of constituents could not be evaluated relative to distance downstream. Elliot and others (2006) showed almost no increase in specific conductance with distance downstream in Baker Creek to the park boundary.

The water sample collected from Baker Creek (site 1) also had a low concentration of strontium. A variety of granite and quartzite formations are present in the southern Snake Range and other researchers have characterized the isotopic composition of these rocks. For instance, Lee and others (1986) reported a ${ }^{87} \mathrm{Sr} /{ }^{86} \mathrm{Sr}$ ratio of 0.79620 permil for Prospect Mountain Quartzite and Prudic and Glancy (2009) reported a value of 0.72695 permil for Tertiary granite. These values are 
considerably higher than those reported for the Pole Canyon two-mica granite (fig. 9). The ${ }^{87} \mathrm{Sr} /{ }^{86} \mathrm{Sr}$ ratio of the water collected from the creek did not reflect the dissolution of carbonates but rather showed a greater similarity to what would be expected from either granite or quartzite (fig. 9). Given the relatively low concentrations of both calcium and magnesium and low alkalinity, these findings substantiate minimal dissolution of carbonate rocks in tributary sources of water to the stream upstream of the point from which the sample was collected. The sample from Baker Creek also had the lowest concentration of uranium $(0.1 \mu \mathrm{g} / \mathrm{L})$ than any other sampling site evaluated as part of this study, with a ${ }^{234} U /{ }^{238} U$ ratio similar to those observed for water samples collected from Pole Canyon Creek (site 3) and Model Cave (site 4; table 3, fig. 10A,B).

Pole Canyon Creek: Distinguishing geochemical characteristics of the water sample collected from Pole Canyon Creek (site 3) relative to the other streams sampled as part of this study, include relatively high concentrations of chloride, silicon dioxide, sodium, strontium, and sulfate (appendix 2, table 2-1). The water sample collected from Pole Canyon Creek had the highest uranium concentration $(11 \mu \mathrm{g} / \mathrm{L})$ and is the most characteristic feature of this water compared with all other waters collected, including those collected from springs and caves, during this study (fig. 10A). It is likely that the granitic rocks prevalent in the headwaters of this stream are the source of this uranium. Lee and Christiansen (1983) found zircon present in the granite, with uranium concentrations ranging from about 500 to $5,000 \mathrm{mg} / \mathrm{kg}$. The geology surrounding the site where water was collected from Pole Canyon Creek is predominantly Prospect Mountain Quartzite and Pioche Shale (fig. 2).

The strontium isotope ratio $\left({ }^{87} \mathrm{Sr} /{ }^{86} \mathrm{Sr}\right)$ in the sample collected from Pole Canyon Creek ( 0.71566 permil) appears to be similar to the two-mica granite (fig. 9); however, the high concentration of strontium suggests that the source of strontium is from a more weatherable substrate (fig. 9). The ${ }^{234} \mathrm{U} /{ }^{238} \mathrm{U}$ ratio in the water sample from Pole Canyon Creek was 1.244, similar to both the Baker Creek and Model Cave water samples.

Wheelers Deep Cave: In 2003, 2 and $5 \mathrm{ft}^{3} / \mathrm{s}$ of water was lost from Baker Creek from an area upstream to one downstream of both Wheelers Deep (site 2) and Model (site 4) Caves (Elliott and others, 2006; fig. 11). It is possible that the water lost from the channel could be entering the caves along this reach of the creek. The entrance of Wheelers Deep Cave is located about $84 \mathrm{ft}$ above Baker Creek and has been mapped to a depth of $84 \mathrm{ft}$ below the level of Baker Creek where small streams within the cave have been found (Lange, 1958; fig. 11). Bridgemon (1966) determined from physical evidence and dye tracing that water from Baker Creek entered Wheelers Deep Cave when creek water was diverted into Dynamite Cave either naturally, as peak runoff, or when it was intentionally diverted into the cave. The connection is presently blocked by a large embankment of alluvial deposits. The loss of flow from Baker Creek along the narrows reported by Elliott and others (2006) have been found to be due to losses to a cave (ponar) located about $100 \mathrm{ft}$ downstream 


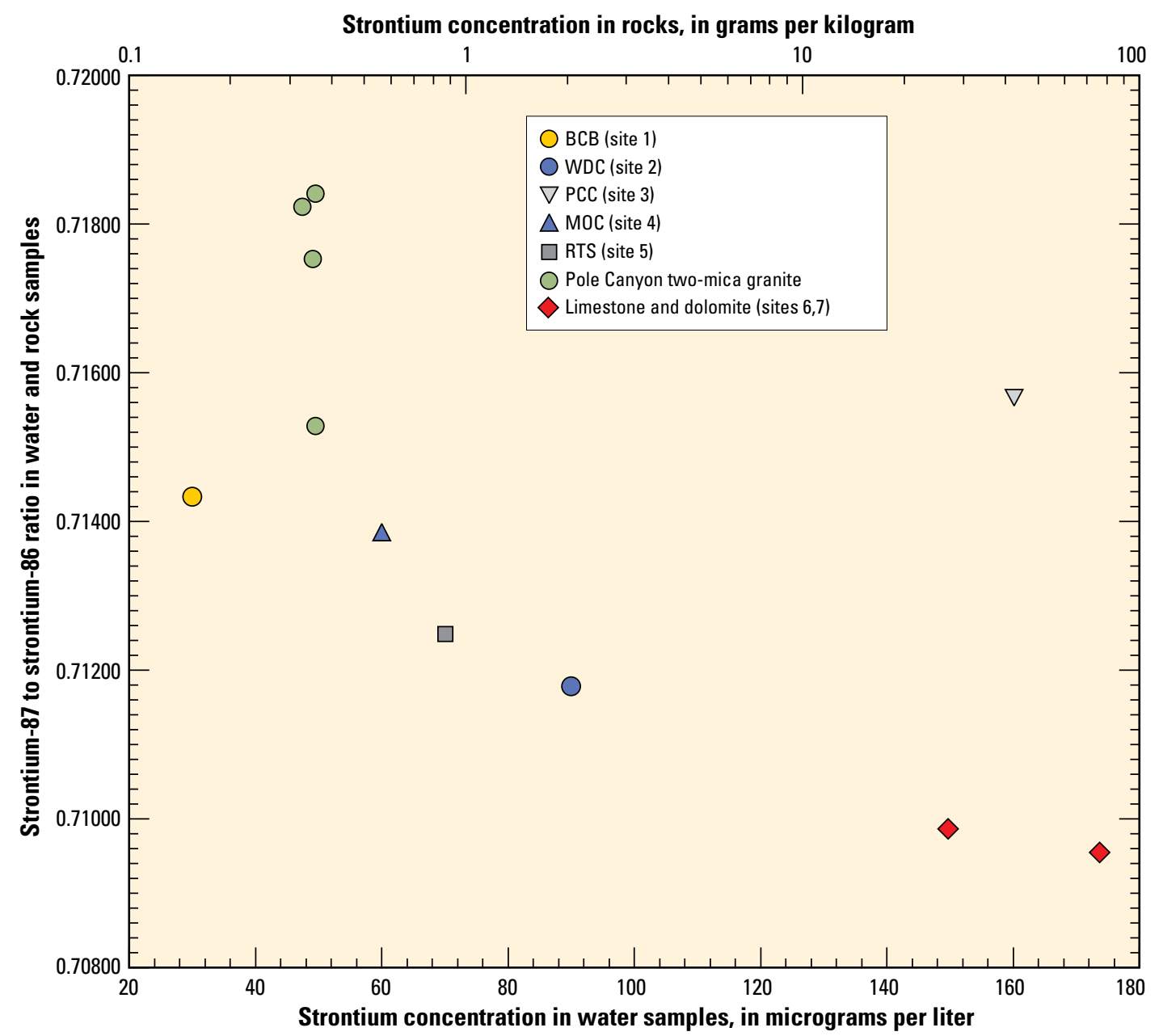

Figure 9. Relation between strontium concentration and strontium-87 to strontium-86 isotope ratios in water and rock samples collected from selected sites in the upper Baker Creek drainage in Great Basin National Park, February 2009. Data for Pole Canyon twomica granite from Lee and others, (1986). 

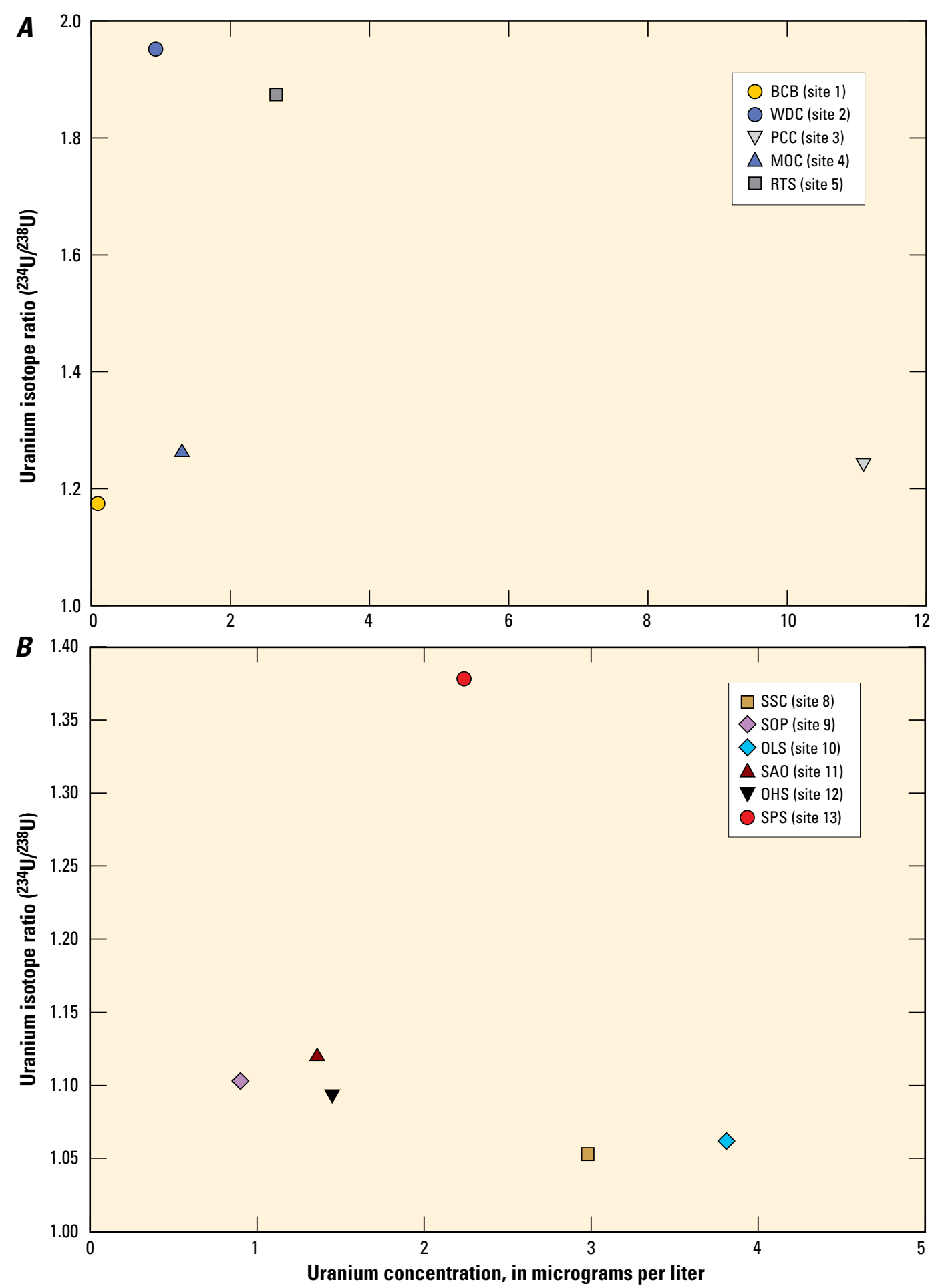

Figure 10. Relation between uranium concentration and isotope ratio $\left({ }^{234} \mathrm{U} / 238 \mathrm{U}\right)$ in water samples collected from selected streams, springs, and caves in the $A$, upper Baker, and B, upper Snake Creek drainages in Great Basin National Park, Nevada, February 2009. 


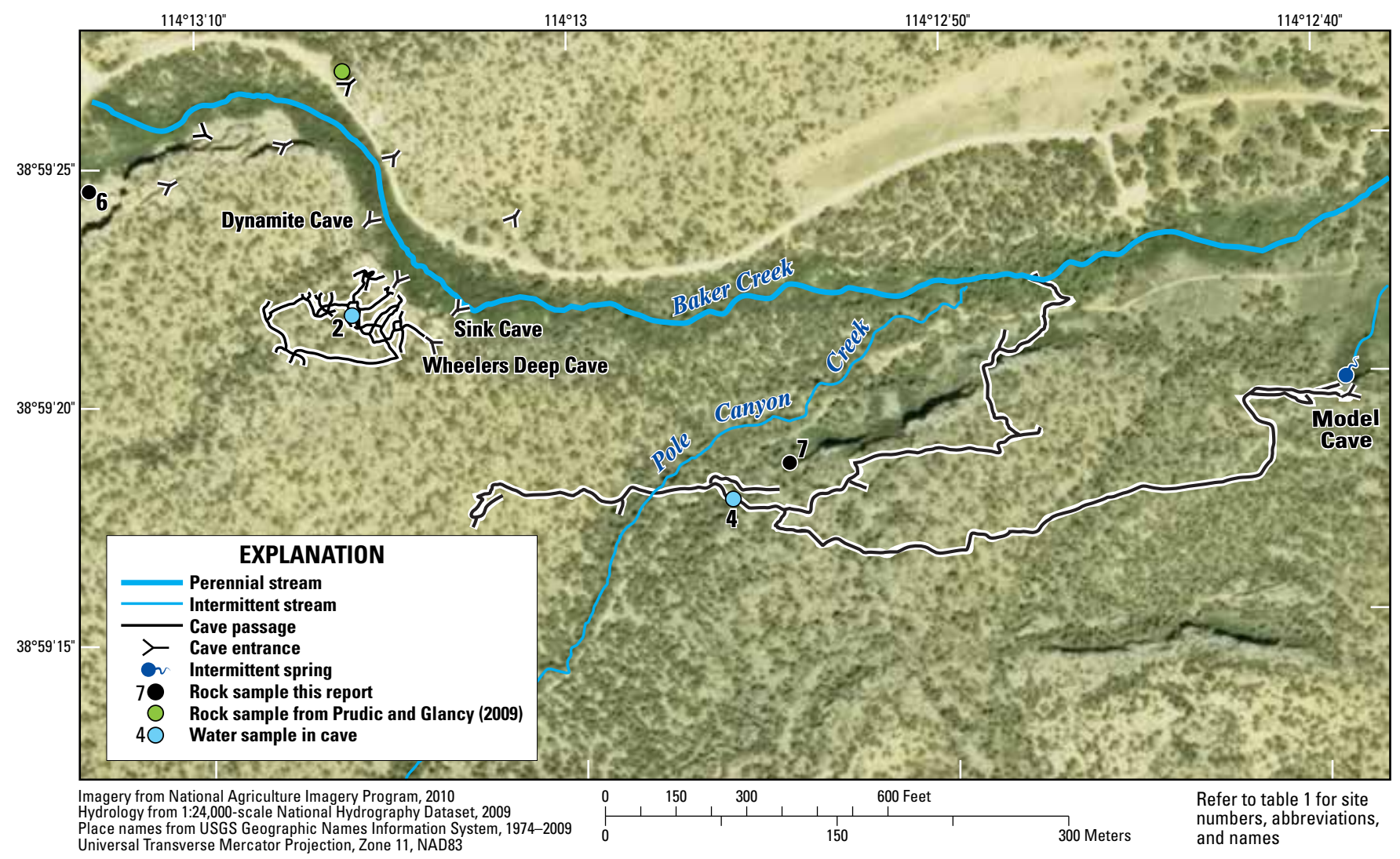

Figure 11. Location of sampling sites and the extent of Wheelers Deep and Model Caves in relation to Baker and Pole Canyon Creeks in the upper Baker Creek drainage, Great Basin National Park, Nevada.

of Dynamite Cave on the south bank of the creek that was unknown to investigators during the 1950s and 1960s (Bridgemon, 1966). This cave is locally called "Sink Cave" (fig. 11).

Water samples from Wheelers Deep Cave (site 2) were collected from a cobble lined stream flowing at about $0.1 \mathrm{ft}^{3} / \mathrm{s}$ within the cave. Generally, the water sample collected from Wheelers Deep Cave had similar alkalinity, specific conductance, and concentrations of calcium and magnesium as the sample collected from Pole Canyon Creek (site 3); however, the creek had higher concentrations of chloride, strontium, and uranium (figs. 9, 10A, 12A; appendix 2, table 2-1).

Wheelers Deep Cave continues to form by dissolution of the host limestone as evident by the a perennial stream in the cave, evidence of secondary calcite deposition during periods of low flow, and dissolution during periods of flooding (Lange, 1958). Generally, water collected from Wheelers Deep Cave had higher concentrations of bicarbonate, boron, calcium, chloride, magnesium, and strontium than samples collected from Baker Creek (appendix 2, table 2-1). The $\delta \mathrm{D}$ and $\delta^{18} \mathrm{O}$ isotope data show that Baker Creek (site 1) and Pole Canyon Creek (site 3) water are both lighter with respect to these isotopes than water collected from Wheelers Deep Cave (fig. 12B). Although the difference between the $\delta \mathrm{D}$ and $\delta^{18} \mathrm{O}$ ratios for Wheelers Deep Cave and the creeks is outside what may be considered due to analytical variability, the isotope values do not deviate from the meteoric water line to any great extent for any of the three sites (fig. $4 B$ ).

The strontium isotope signature for water in Wheelers Deep Cave $(0.71178$ permil) lies between those obtained for the Pole Canyon Limestone and Pole Canyon two mica granite (fig. 9). The strontium isotope values were different among water samples collected from Wheelers Deep Cave, Baker Creek, and Pole Canyon Creek. The granites in the southern Snake Range are known for their variability in chemical composition over relatively small areas (Lee and others, 1986) and therefore it is not surprising that the ${ }^{234} \mathrm{U} / 238 \mathrm{U}$ value for the water sample collected from Wheelers Deep Cave (1.951) is different than those of Baker Creek (1.174), Pole Canyon Creek (1.244), and Model Cave (1.262; table 3; fig. 10A).

Model Cave: Model Cave was identified previously as an extensive cave in the Baker Creek drainage and the second longest cave in the State of Nevada (Lange, 1958; Bridgemon, 1966). The entrance to Model Cave is located in a southfacing cliff wall along Baker Creek about $800 \mathrm{ft}$ downstream from the confluence of Baker and Pole Canyon Creeks with its extent beneath Pole Canyon Creek (fig. 11). Within the innermost $360 \mathrm{ft}$ of the cave, a free-flowing stream was observed which is only accessible in some winters when the water 


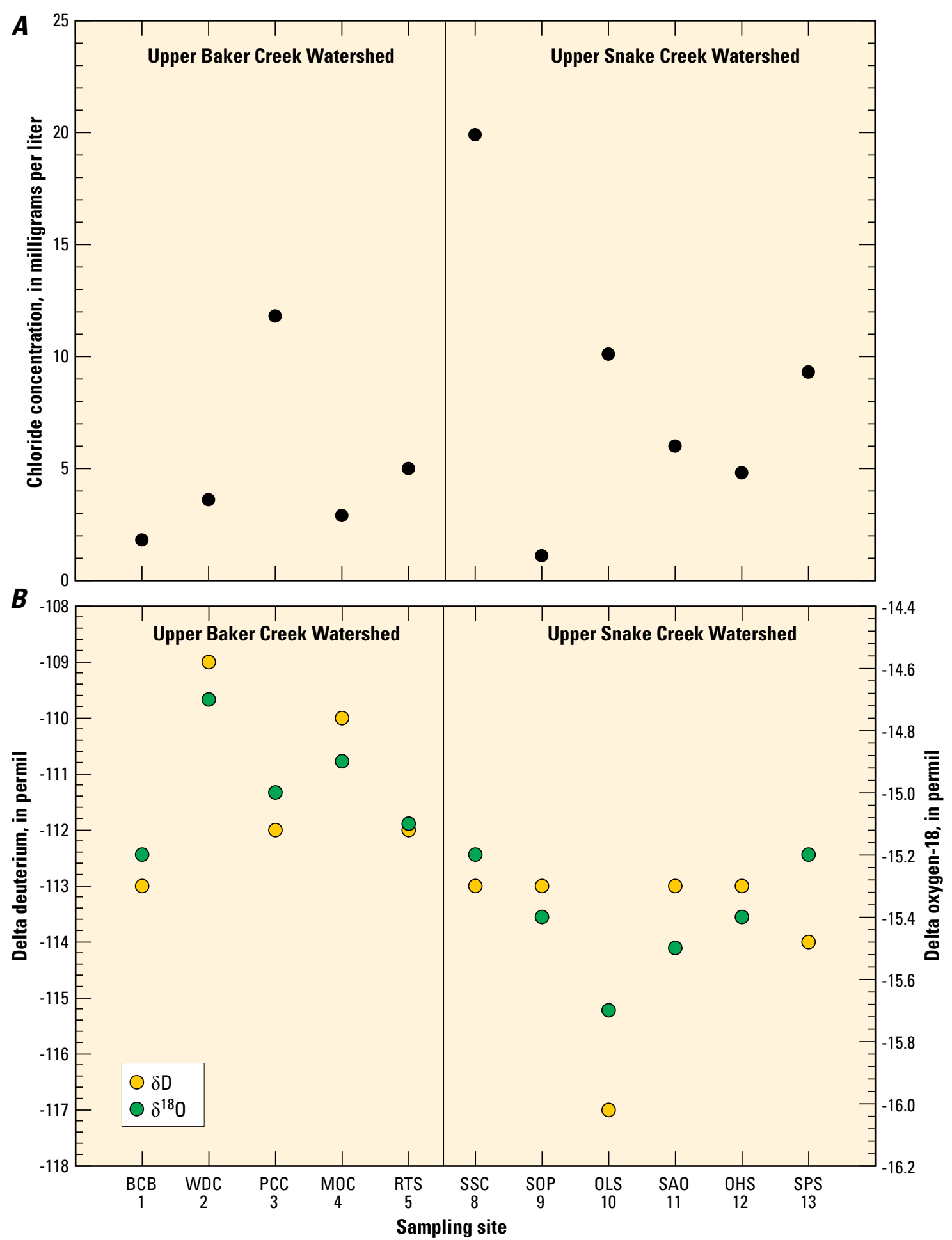

Figure 12. Comparison of $A$, chloride concentration, and $B$, delta deuterium $(\delta D)$ and delta oxygen-18 $\left(\delta^{18} 0\right)$ values in water samples collected from selected streams, springs, and caves in the upper Baker Creek and Snake Creek watersheds in Great Basin National Park, Nevada, February 2009. 
level in the cave is low. The stream substrate is composed of evenly sorted rounded granite/quartz cobbles with occasional limestone rockfall (Lange, 1958). The source of the stream is a spring emanating from the wall of the cave about $70 \mathrm{ft}$ from the end of the cave where Lange (1958) estimated a discharge of about 0.25 to $0.50 \mathrm{ft}^{3} / \mathrm{s}$ (Lange, 1958). Lange (1958) proposed that the flow of water within Model Cave originated as glacial melt water and at one time fed Baker Creek (Lange, 1958). Generally, the water level in the cave is the highest in the early summer, coinciding with peak streamflows in nearby streams. During this time, water often discharges from the cave as a spring that flows into Baker Creek; this spring is located about $30 \mathrm{ft}$ lower than the cave entrance (fig. 11). In 2005, when streamflows were extremely high, water flowed out of the mouth of Model Cave. Samples collected from caves as part of this study were from a hand-made pool dug in the streambed underneath the cobble in Model Cave.

Results of this study showed that, generally, water collected from Model Cave (site 4) had higher concentrations of most of the major constituents than did water from Baker Creek (site 1; appendix 2, table 2-1). The concentrations of chloride in samples collected from Model and Wheelers Deep Caves were higher relative to the sample collected from Baker Creek (site 1) and similar between them (sites 2, 4; fig. 12A). The $\delta \mathrm{D}$ and $\delta^{18} \mathrm{O}$ values for water samples collected from the caves were similar (fig. $12 B$ ); however, the $\delta \mathrm{D}$ and $\delta^{18} \mathrm{O}$ values for Model Cave were also within analytical variability of those determined for Baker (site 1) and Pole Canyon Creek (site 3) samples (table 3). Model Cave is hydrologically connected to Baker Creek; however, it is unlikely that this cave is hydrologically connected to Pole Canyon Creek (Bridgemon, 1966).

Although the network of passages of Model Cave extends underneath Pole Canyon Creek, the strontium concentration was considerably lower in water from Model Cave (site 4) than in the water collected from Pole Canyon Creek (site 3; figs. 9, 11; table 3). The strontium isotope analysis for water collected from Model Cave (site 4) showed greater similarity to the sample from Baker Creek (site 1) than from Wheelers Deep Cave (site 2; fig. 9; table 3).

The water in Model Cave had a higher uranium concentration $(1.3 \mu \mathrm{g} / \mathrm{L})$ than in the sample collected from Wheelers Deep Cave $(0.9 \mu \mathrm{g} / \mathrm{L})$; however, the relative difference in concentrations was small (36 percent). Although the isotopic signature for ${ }^{234} \mathrm{U} /{ }^{238} \mathrm{U}$ in the sample collected from Model Cave (1.262) is similar to that collected from Pole Canyon (1.244) and Baker (1.174) Creeks, the general geochemical characteristics of the water sampled from Model Cave differ from those of the water in Pole Canyon Creek (fig. 10A; appendix 2, table 2-1). These results support the conclusions of Bridgemon (1966) that a hydrologic connection exists between Baker Creek and Model Cave.

Rosethorn Spring: Rosethorn Spring (site 5) is located at the most downgradient point of all the sampling sites in the upper Baker Creek drainage evaluated as part of this study (fig. 2). This spring is located in alluvium at the contact with Tertiary deposits along the Southern Snake Range detachment.
Rosethorn Spring had higher alkalinity, specific conductance, and concentrations of calcium, magnesium, chloride, strontium, and uranium relative to Baker Creek (appendix 2, table 2-1). The strontium isotope value for Rosethorn Spring lies between the strontium signature found for limestone samples collected from the Baker Creek area and possibly a type of granite similar to that found near Wheelers Deep Cave (fig. 9). The ${ }^{234} \mathrm{U} /{ }^{238} \mathrm{U}$ ratio for Rosethorn Spring (1.874) is most similar to that for Wheelers Deep Cave (1.951). These results do not preclude a hydrologic connection between the spring and Baker Creek.

\section{Upper Snake Creek Drainage}

Snake Creek: The water samples collected from Snake Creek (sites 9,11) had low to moderate values of specific conductance, bicarbonate, and concentrations of calcium and magnesium relative to the other water samples collected as part of this study (figs. 2, 5, 6; appendix 2, table 2-1). Water samples collected from the point where the by-pass pipeline discharges back into the creek (site 9) were considered representative of conditions upstream of the pipeline (fig. 3). Concentrations of these constituents and others (including chloride) increased with distance downstream from Snake Creek at the pipeline outlet (site 9) to Outhouse Spring (site 11; figs. 5, 6, 12A). During baseflow conditions, which were evident during the time samples for this study were collected, springs discharge directly to the creek channel supplying water to the stream. Increases in constituent concentrations could be the result of these spring discharges to the stream.

The strontium isotope signature was different for water collected from Snake Creek at the outlet of the pipeline (site 9; 0.71030) and Snake Creek above Outhouse Spring (site 11; 0.71283). The upstream sample from the creek (site 9) had a ${ }^{87} \mathrm{Sr} /{ }^{86} \mathrm{Sr}$ ratio characteristic of the carbonate and granitic rocks in the Snake Creek drainage (fig. 13). The strontium concentrations in intrusive rocks in the upper Snake Creek drainage (Lee and others, 1986) are higher relative to those determined in carbonate samples collected from the area (fig. 13; table 2). This phenomenon is likely due to the assimilation of limestone into the intrusive rock during genesis (Lee and Van Loenen, 1971). Given the low strontium concentration and the similarity in the ${ }^{87} \mathrm{Sr} /{ }^{86} \mathrm{Sr}$ ratio in Snake Creek at site 9 to carbonate and intrusive rocks, the data suggest that the chemistry of the water upstream of the pipeline is minimally influenced by rock weathering processes (fig. 13). $\mathrm{The}{ }^{87} \mathrm{Sr} /{ }^{86} \mathrm{Sr}$ ratio in water collected from the creek above Outhouse Spring (site 11) showed a mixed characteristic of the intrusive rock described by Lee and others (1986), represented as an outlier datapoint for intrusive rock in figure 13 , and the sedimentary rocks composed mostly of carbonate (fig. 13).

Outhouse Spring: The general geochemical characteristics were so similar between Snake Creek above Outhouse Spring (site 11) and Outhouse Spring (site 12) that a connection between the creek and spring is evident. Generally, relative concentrations of many of the constituents in water 


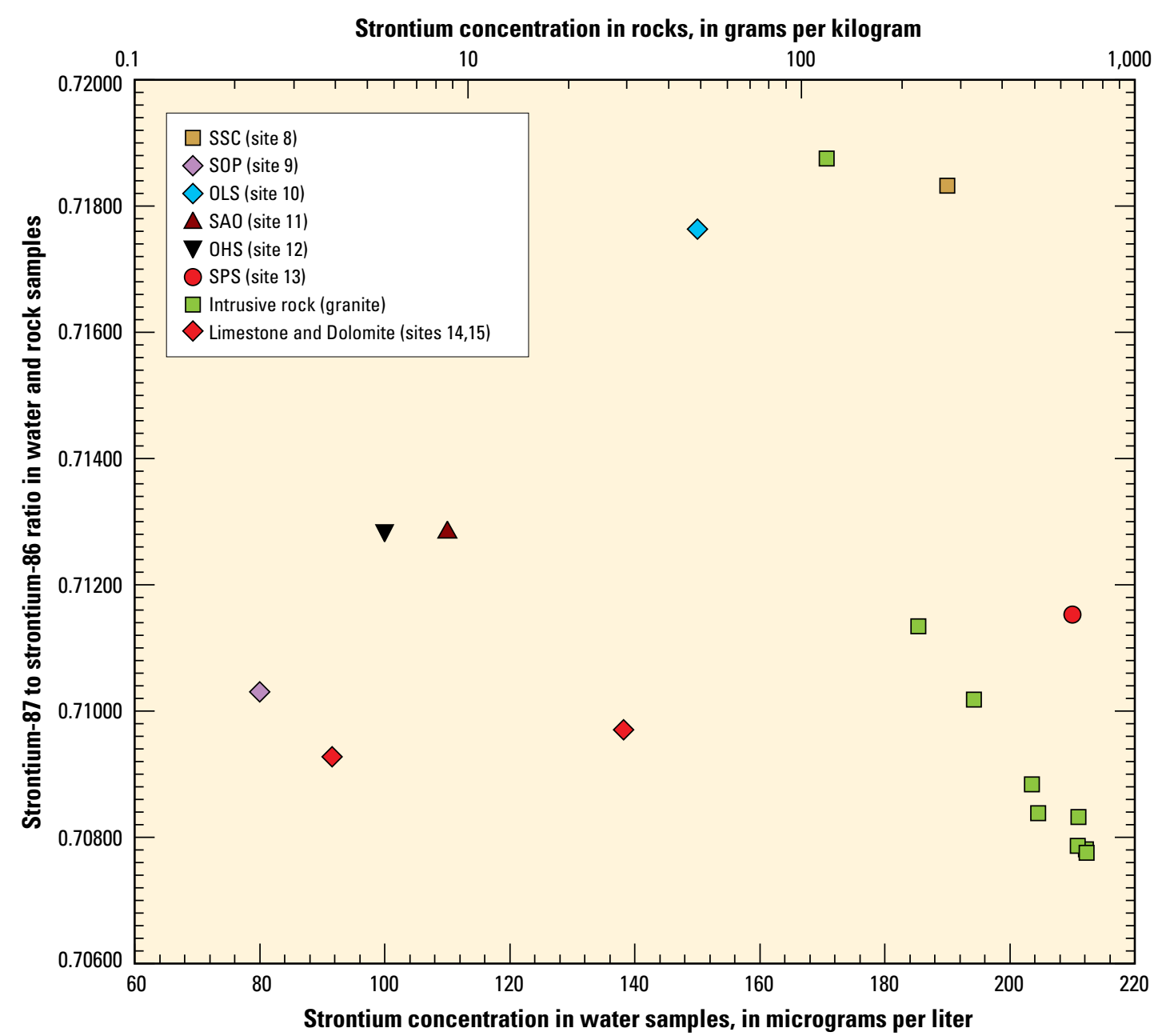

Figure 13. Relation between strontium concentration and strontium- 87 to strontium- 86 isotope ratios in water and rock samples collected from selected sites in the upper Snake Creek drainage in Great Basin National Park, February 2009. Data for intrusive rock (granite) from Lee and others (1986).

from Outhouse Spring were within 25 percent (including chloride, sodium, strontium, and sulfate) of those in the creek (site 11); in some cases the similarity was within 10 percent (appendix 2, table 2-1). Bicarbonate and specific conductance were a little higher in water sampled from Outhouse Spring relative to Snake Creek (site 11); however, this is not unexpected as the water flowed through carbonate rock or alluvium prior to being discharged from the spring (figs. 5, 6). The ${ }^{234} \mathrm{U} /{ }^{238} \mathrm{U}$ ratio of the spring water was similar to that of the stream water (fig. $10 B$ ). The $\delta \mathrm{D}, \delta^{18} \mathrm{O}$, and ${ }^{87} \mathrm{Sr} /{ }^{86} \mathrm{Sr}$ values obtained from samples of both Snake Creek above Outhouse Spring and discharge from Outhouse Spring are nearly the same, further substantiating the similarity between the waters (table 3; figs. 12B, 13).

Squirrel Spring Cave: Squirrel Spring Cave (site 8) was the most upgradient point sampled in the upper Snake Creek drainage for the purposes of this investigation (table 1; figs. 2, 3). Squirrel Spring Cave is located in Quaternary alluvium surrounded by Ordovician-Silurian Fish Haven and Laketown dolomites, from which a sample was collected at the entrance of the cave (site 14). During summer months, water frequently rises to levels within Squirrel Spring Cave that result in water flowing from the mouth of the cave (fig. 3). The water sample was collected from a standing pool of water approximately $50 \mathrm{ft}$ into the cave at its base (fig. 3). Geochemical characteristics of water sampled from Squirrel Spring Cave showed a general enrichment of most constituents relative to samples from Snake Creek (sites 9, 11; appendix 2 , table $2-1)$. The values for $\delta \mathrm{D}$ (-113 permil) and $\delta^{18} \mathrm{O}(-15.2$ permil) for water collected from Squirrel Spring Cave are within analytical variability compared with samples collected from Snake Creek (site 9; fig. 12), suggesting a common source of recharge for both the stream and the cave.

The sum-of-constituents and chloride concentrations in the water sample from Squirrel Spring Cave are the highest of any sample collected as part of this study (figs. 5, 12A). Values of $\delta \mathrm{D}$ and $\delta^{18} \mathrm{O}$ do not appear to show evidence of evapoconcentration within the cave, thereby lending to the hypothesis that another process (either dissolution of salts deposited in the cave or from transpiration) is responsible for concentrating chloride in this water. 
The ${ }^{234} \mathrm{U} /{ }^{238} \mathrm{U}$ ratio was a little lower and the concentration of uranium relatively high in the water sample collected from Squirrel Spring Cave relative to the samples of stream water and Outhouse Spring (fig. 10B). The value for the ${ }^{87} \mathrm{Sr} /{ }^{86} \mathrm{Sr}$ isotopic ratio in water samples from Squirrel Spring Cave deviates from the ${ }^{87} \mathrm{Sr} r{ }^{86} \mathrm{Sr}$ values associated with carbonate and most of the intrusive rock (granite) sampled from the Snake Creek drainage (fig. 13). The relatively high concentrations of strontium and similarity of the ${ }^{87} \mathrm{Sr}{ }^{86} \mathrm{Sr}$ value to one of the granite rock samples described by Lee and others (1986) suggests that strontium could be leaching from intrusive rocks prior to water discharging into the cave.

Outlet Spring: The specific conductance and sum-ofconstituents concentration in water samples from Outlet Spring (site 10) were within the moderately high range for samples collected as part of this study (fig. 5). Concentrations of most of the constituents evaluated were higher in the water discharging from Outlet Spring relative to that in the water sample collected from Snake Creek at the outlet of the pipeline (site 9), reflecting water-rock interactions as the water flowed underground to the point of discharge (appendix 2, table $2-1)$. The values for $\delta \mathrm{D}\left(-117\right.$ permil) and $\delta^{18} \mathrm{O}(-15.7$ permil) for water collected from Outlet Spring represent the lightest isotopic compositions for these isotopes in all the samples collected as part of this study and lie outside what is expected for analytical uncertainty (fig. 12B). Therefore, it is unlikely that the water discharging from Outlet Spring originates from Snake Creek, but rather is likely recharged at higher altitudes within the drainage.

Given the similarity between the ${ }^{87} \mathrm{Sr} /{ }^{86} \mathrm{Sr}$ ratios in water samples from Outlet Spring (site 10) and Squirrel Spring Cave (site 8, fig. 13), it appears as though water discharging from Outlet Spring likely flowed through areas where intrusive rock was present. The water emanating from the spring is in an area of Pioche Shale which could also possibly be influencing water chemistry results. The concentration of uranium in water from Outlet Spring also was higher than in the other samples from the upper Snake Creek drainage, suggesting that water discharging from the spring has been in contact with granitic rocks in the area (either outcrops or cobbles present in alluvium overlying consolidated rock). The ${ }^{234} U /{ }^{238} U$ ratio for water collected from Outlet Spring was similar to that from Squirrel Spring Cave (fig. 10B).

Spring Creek Spring: Spring Creek Spring (site 13) is the most downgradient site sampled as part of this study within the upper Snake Creek drainage. Spring Creek Spring discharges from Fish Haven/Laketown Dolomites, alluvial glacial deposits, and Tertiary rocks at a fault contact (Elliot and others, 2006). The specific conductance and sum-of-constituents concentration for water discharging from this spring are high with respect to other samples collected as part of this study, second only to Squirrel Spring Cave (fig. 5). As with the other samples of water collected from springs and caves, many of the constituents from the spring were higher relative to those in samples collected from streams as a result of water flowing underground to the point of discharge (appendix 2, table 2-1).
The $\delta \mathrm{D}$ and $\delta^{18} \mathrm{O}$ values for samples from Spring Creek Spring are within analytical limits of the values for samples collected from Snake Creek (sites 9, 11; fig. 12B).

Water samples from Spring Creek Spring (site 13) had high concentrations of strontium with a ${ }^{87} \mathrm{Sr} /{ }^{86} \mathrm{Sr}$ ratio similar to the carbonate and intrusive rock samples collected from the area (fig. 13; table 3). The spring is located in a largely karst geological setting and the strontium concentration and ${ }^{87} \mathrm{Sr} /{ }^{86} \mathrm{Sr}$ ratio for the spring water suggests a strong influence of carbonate dissolution on the water chemistry. A distinguishing characteristic of Spring Creek Spring water is the relatively unique ${ }^{234} \mathrm{U} /{ }^{238} \mathrm{U}$ value relative to the other sites sampled from the upper Snake Creek drainage (fig. 10B).

\section{Estimated Recharge Altitudes and Residence Times}

Estimated recharge altitudes and temperatures were evaluated using concentrations of dissolved gases in samples collected from selected springs and caves within the upper Baker and Snake Creek drainages (table 4). A minimum temperature of $0.5^{\circ} \mathrm{C}$ that reasonably represents melting ice, was used as the lower boundary for recharge temperature because recharge generally originates as winter precipitation (fig. 4); the maximum recharge temperature was derived using a decrease in temperature with increasing altitude determined by Prudic and Glancy (2009) for the Lehman Creek drainage (table 5). Maximum recharge temperatures determined using a rate of $-2{ }^{\circ} \mathrm{C}$ per 1,000 -ft gain in altitude were then evaluated against maximum temperatures calculated using the rate determined by Hershey and others (2007) for eastern Nevada; all maximum temperatures appeared reasonable when evaluated using both available rates determined for the area (table 5). The increasing difference between the two estimated recharge temperatures with increasing altitude is likely the result of the lower temperatures where the relative difference between values becomes increasingly large.

Recharge altitudes were evaluated iteratively in $500-\mathrm{ft}$ increments using estimated recharge temperatures and excess air data that were calculated using the solubility of argon, nitrogen, carbon dioxide, and methane gases. The ranges in possible estimated recharge altitudes that were within the boundary conditions of site altitude, a minimum temperature of $0.5^{\circ} \mathrm{C}$, and a maximum temperature as determined using the decrease in temperature with altitude provided by Prudic and Glancy (2009) were bracketed between 2,500 and 4,000-ft windows (table 6). The actual recharge altitudes for the selected springs and caves in the upper Baker and Snake Creek drainages may be within these ranges in altitude but remain uncertain given the mountainous topography and complex network of passages within the carbonate rocks. The calculations used in the back-solving routine appear to be relatively insensitive to changes in assumed recharge altitudes where Prudic and Glancy (2009) found that an increase in estimated 
Table 4. Concentration of chlorofluorocarbons and dissolved gases in water samples collected from selected streams, springs, and caves in the upper Baker and Snake Creek drainages in Great Basin National Park, Nevada, February 2009.

[Abbreviations: CFC-11, trichlorofluoromethane; CFC-12, dichlorodifluoromethane; CFC-113, trichlorotrifluoroethane; - , not determined; ND, not detected; E, estimated]

\begin{tabular}{|c|c|c|c|c|c|c|c|c|}
\hline Site name & \multicolumn{3}{|c|}{$\begin{array}{c}\text { Chlorofluorocarbons } \\
\text { (picograms per kilogram) }\end{array}$} & \multicolumn{5}{|c|}{$\begin{array}{c}\text { Dissolved Gases } \\
\text { (milligrams per liter) }\end{array}$} \\
\hline \multirow{2}{*}{ Site 2-Wheelers Deep Cave } & 640 & 310 & 80 & \multirow{2}{*}{0.589} & \multirow{2}{*}{2.0} & \multirow{2}{*}{ ND } & \multirow{2}{*}{15.6} & \multirow{2}{*}{10.6} \\
\hline & 630 & 310 & 79 & & & & & \\
\hline \multirow{2}{*}{ Site 5-Rosethorn Spring } & 570 & 270 & 62 & \multirow{2}{*}{0.587} & \multirow{2}{*}{19} & \multirow{2}{*}{ ND } & \multirow{2}{*}{16.2} & \multirow{2}{*}{8.2} \\
\hline & 570 & 270 & 62 & & & & & \\
\hline \multirow{2}{*}{ Site 8-Squirrel Spring Cave } & 400 & 200 & 46 & \multirow{2}{*}{0.47} & \multirow{2}{*}{13} & \multirow{2}{*}{ ND } & \multirow{2}{*}{11.6} & \multirow{2}{*}{3.6} \\
\hline & 380 & 200 & 47 & & & & & \\
\hline Site $11-$ Snake Creek above Outhouse Spring & - & - & - & - & 4.0 & - & - & 11.6 \\
\hline \multirow{2}{*}{ Site 12 - Outhouse Spring } & 600 & 340 & 70 & \multirow{2}{*}{0.645} & \multirow{2}{*}{5.8} & \multirow{2}{*}{ ND } & \multirow{2}{*}{17.5} & \multirow{2}{*}{8.2} \\
\hline & 620 & 330 & 70 & & & & & \\
\hline \multirow{2}{*}{ Site 13 - Spring Creek Spring } & 350 & 180 & 39 & \multirow{2}{*}{0.533} & 1 & & & \\
\hline & 340 & 180 & 38 & & 11 & ND & 14.3 & 8.1 \\
\hline
\end{tabular}

Table 5. Temperature boundary conditions for estimating recharge altitude based on temperature of melting ice and decrease in air temperature with increasing altitude.

[Abbreviations: ${ }^{\circ} \mathrm{C}$, degrees Celsius; - - , not evaluated; $<$, less than]

\begin{tabular}{|c|c|c|c|c|}
\hline $\begin{array}{c}\text { Assumed } \\
\text { recharge } \\
\text { altitude } \\
\text { (feet) }\end{array}$ & $\begin{array}{c}\text { Minimum } \\
\text { temperature } \\
\text { (melting ice, }{ }^{\circ} \mathrm{C} \text { ) }\end{array}$ & $\begin{array}{l}\text { Maximum temperature } \\
\text { based on rate of Prudic } \\
\text { and Glancy (2009), }{ }^{\circ} C^{2}\end{array}$ & $\begin{array}{c}\text { Maximum tempera- } \\
\text { ture based on rate of } \\
\text { Hershey and others } \\
\text { (2007), }{ }^{\circ} C^{2}\end{array}$ & $\begin{array}{c}\text { Relative difference } \\
\text { between maximum } \\
\text { temperatures }\end{array}$ \\
\hline 6,500 & 0.5 & 9.7 & 9.7 & 0 \\
\hline 7,000 & 0.5 & 8.7 & 8.6 & 0.012 \\
\hline 7,500 & 0.5 & 7.7 & 7.6 & 0.013 \\
\hline 8,000 & 0.5 & 6.7 & 6.5 & 0.030 \\
\hline 8,500 & 0.5 & 5.7 & 5.4 & 0.054 \\
\hline 9,000 & 0.5 & 4.7 & 4.4 & 0.066 \\
\hline 9,500 & 0.5 & 3.7 & 3.3 & 0.114 \\
\hline 10,000 & 0.5 & 2.7 & 2.2 & 0.204 \\
\hline 10,500 & 0.5 & 1.7 & 1.2 & 0.345 \\
\hline 11,000 & 0.5 & 0.7 & $<0.5$ & - \\
\hline
\end{tabular}

${ }^{1}$ The maximum altitude was that where estimated maximum temperatures did not fall below $0.5^{\circ} \mathrm{C}$ but were below the maximum possible altitudes of the respective watersheds (Baker Creek drainage, Wheeler Peak at 13,063 feet; Snake Creek drainage, Pyramid Peak at 11,926 feet). The lowest possible recharge altitude was the altitude of the sampling site or, for the caves, the altitude at the cave entrance; however, standing pools of water in caves may be recharged by water sources below the altitude of the cave entrance but this was not considered as part of this study. Minimum assumed recharge altitude evaluated was 6,500 feet, based on the lowest altitude sampling site included in this study $(6,200$ feet).

$2-2.1{ }^{\circ} \mathrm{C}$ per 1,000 -foot gain in altitude (Hershey and others, 2007); $-2.0^{\circ} \mathrm{C}$ per 1,000-foot gain in altitude (Prudic and Glancy, 2009). recharge altitude of $1,000 \mathrm{ft}$ causes a decrease in the recharge temperature of about $1^{\circ} \mathrm{C}$. Therefore, it is unlikely that the variations in altitude $(2,500$ to $4,000 \mathrm{ft}$ ) have influenced the estimated recharge temperatures used to determine residence times from $\mathrm{CFC}$ concentrations to any appreciable extent.

For the purposes of this study, the relation between known CFC concentrations in the atmosphere and mixing ratios of the various $\mathrm{CFC}$ compounds (Plummer and Busenberg, 2011) were used to evaluate apparent age (residence time) of groundwater discharging into selected caves and from selected springs in the upper Baker and Snake Creek drainages. Given the influence of pressure and temperature on CFC volatility from aqueous solution, the estimated recharge altitudes and temperatures from dissolved gases were used in the calculation of groundwater residence time.

Within the upper Baker Creek drainage the results of this study suggest that the residence time of water discharging into Wheelers Deep Cave (site 2) and from Rosethorn Spring (site 5) as of 
Table 6. Estimated recharge altitudes, temperatures, and excess air concentrations for selected sites in the upper Baker and Snake Creek drainages in Great Basin National Park, Nevada, February 2009.

[Abbreviations: $\mathrm{ft}$, feet; ${ }^{\circ} \mathrm{C}$, degrees Celsius; cc, cubic centimeters; - , all evaluations outside boundary conditions]

\begin{tabular}{|c|c|c|c|c|c|}
\hline Sampling site number, name, and abbreviation & $\begin{array}{l}\text { Sampling site } \\
\text { altitude (ft) }\end{array}$ & $\begin{array}{c}\text { Maximum } \\
\text { altitude in } \\
\text { watershed (ft) }\end{array}$ & $\begin{array}{l}\text { Range in esti- } \\
\text { mated recharge } \\
\text { altitude (ft) }\end{array}$ & $\begin{array}{l}\text { Range in esti- } \\
\text { mated recharge } \\
\text { temperature }\left({ }^{\circ} \mathrm{C}\right)\end{array}$ & $\begin{array}{c}\text { Range in excess } \\
\text { air (cc) }\end{array}$ \\
\hline Site 2-Wheelers Deep Cave (WDC) & 6,977 & 13,063 & $7,000-11,000$ & $0.7-6.1$ & $0.4-0.7$ \\
\hline Site 5-Rosethorn Spring (RTS) & 6,460 & 13,063 & $6,500-10,500$ & $2.7-6.8$ & $1.5-1.7$ \\
\hline Site 8 -Squirrel Spring Cave $(\mathrm{SSC})^{1}$ & 7,200 & 11,926 & - & - & - \\
\hline Site 10 - Outlet Spring (OLS) & 6,755 & 11,926 & $7,000-10,500$ & $2.4-7.2$ & $1.4-1.6$ \\
\hline Site 12 - Outhouse Spring (OHS) & 6,396 & 11,926 & $6,500-9,000$ & $0.7-4.0$ & $1.2-1.3$ \\
\hline Site 13 - Spring Creek Spring (SPS) ${ }^{2}$ & 6,191 & 11,926 & - & - & - \\
\hline
\end{tabular}

${ }^{1}$ An estimated recharge altitude, recharge temperature, and excess gas volume were not reported for this site because the sample degassed, which resulted in erroneously high recharge temperatures.

${ }^{2}$ An estimated recharge altitude, recharge temperature, and excess gas volume were not reported for this site as the results were inconclusive due to calculated recharge temperatures falling outside the upper range of possible temperatures determined using lapse rates available for the area.

Table 7. Estimated recharge temperatures and age of waters as determined using dissolved gases and chlorofluorocarbons for water samples collected from selected springs and caves in the upper Baker and Snake Creek drainages in Great Basin National Park, Nevada, February 2009.

[Abbreviations: $\mathrm{CFC}$, chlorofluorocarbon; ${ }^{\circ} \mathrm{C}$, degrees Celsius]

\begin{tabular}{|c|c|c|c|c|c|c|}
\hline $\begin{array}{l}\text { Dissolved gas or chlorofluorocarbon } \\
\text { characteristic }\end{array}$ & $\begin{array}{c}\text { Site } 2 \\
\text { Wheelers Deep } \\
\text { Cave }\end{array}$ & $\begin{array}{c}\text { Site } 5 \\
\text { Rosethorn Spring }\end{array}$ & $\begin{array}{c}\text { Site } 8 \\
\text { Squirrel Spring } \\
\text { Cave }\end{array}$ & $\begin{array}{c}\text { Site } 10 \\
\text { Outlet Spring }\end{array}$ & $\begin{array}{c}\text { Site } 12 \\
\text { Outhouse Spring }\end{array}$ & $\begin{array}{l}\text { Site } 13 \\
\text { Spring Creek } \\
\text { Spring }\end{array}$ \\
\hline \multicolumn{7}{|c|}{ Recharge characteristics determined using dissolved-gas data } \\
\hline $\begin{array}{l}\text { Assumed recharge altitude, } \\
\text { in feet above mean sea level }\end{array}$ & 7,000 to 11,000 & 6,500 to 10,500 & Inconclusive $^{1}$ & 7,000 to 10,500 & 6,389 to 6,755 & Inconclusive $^{1}$ \\
\hline Estimated recharge temperature $\left({ }^{\circ} \mathrm{C}\right)$ & 0.7 to 6.1 & 2.7 to 6.8 & Inconclusive $^{1}$ & 2.4 to 7.2 & 0.0 to 14.5 & Inconclusive $^{1}$ \\
\hline \multicolumn{7}{|c|}{ Estimated age of water (years) using respective CFC data } \\
\hline Estimated year of recharge & $\begin{array}{l}\text { Late } 1980 \text { s to } \\
\text { Early } 1990 \mathrm{~s}\end{array}$ & Late $1980 \mathrm{~s}$ & Mid 1980s & $1970 \mathrm{~s}$ & Late $1980 \mathrm{~s}$ & Early $1980 \mathrm{~s}$ \\
\hline Estimated residence time (years) & 10 to 15 & 15 to 25 & 15 to 20 & 60 to 90 & 10 to 25 & 20 to 30 \\
\hline
\end{tabular}

${ }^{1}$ Estimated recharge altitudes could not be determined for two sites as the boundary conditions were not met; the assumed recharge altitude for these sites was characterized as inconclusive.

2009 is less than 25 years, and likely was recharged sometime during the late 1980 s to early 1990s (table 7). The residence time of water discharging into Model Cave (site 4) could not be determined as samples intended for dissolved-gas analyses were not collected from this site.

Within the upper Snake Creek drainage, residence times of water discharging into Squirrel Spring Cave (site 8) and from selected springs ranged from 10 to 90 years (table 7). The longest residence time was estimated for Outlet Spring (site 10; 60 to 90 years), which had moderately high specific conductance, chloride, strontium, and uranium concentrations, and the lightest $\delta \mathrm{D}$ and $\delta^{18} \mathrm{O}$ values (figs. 5, $10 B, 12 A, B$, 13). These results suggest that water discharging from Outlet Spring (site 10) is not originating from Snake Creek (site 9), but rather from precipitation occurring at higher altitudes than for other samples collected as part of this study. Water discharging from Outlet Spring at the time of sampling is estimated to have been recharged sometime during the 1970s.
The estimated residence time of water discharging into Squirrel Spring Cave (site 8) ranged from 15 to 20 years. Although there are some similar geochemical characteristics between water discharging from Squirrel Spring Cave and Outlet Spring, the shorter residence time determined for the cave is due, at least in part, to the karst geology and relatively high flow rates associated with that geological landscape. Outhouse Spring (site 12) and Spring Creek Spring (site 13) had similar estimated residence times where, at the time of sampling, the water discharging from these springs was less than 30 years old (table 7). 


\section{Summary and Conclusions}

Water in caves, discharging from springs, and flowing in streams in the upper Baker and Snake Creek drainages are important natural resources in Great Basin National Park in eastern Nevada. Water and rock samples were collected from 15 sites during February 2009 as part of a series of investigations evaluating the potential for water-resource depletion resulting from the current and proposed groundwater pumping. Many of the water samples collected from the selected caves and springs in the upper Baker and Snake Creek drainages showed geochemical characteristics of the geologic formations through which the waters travelled prior to being discharged into a cave or to the surface from a spring. These relations were used in this preliminary investigation to evaluate the geochemical data for eventual use in elucidating possible sources and hydrologic connections between selected streams, caves, and springs.

Oftentimes the concentrations of constituents in water discharging into the selected caves and from the springs in the upper Baker and Snake Creek drainages were higher relative to concentrations in water sampled from streams. Within each of the upper Baker and Snake Creek drainages, geochemical data showed similarities between the creek and respective springs and caves sampled as part of this study; however, there were a couple of noted exceptions.

Within the upper Baker Creek drainage there is a hydrologic connection between Wheelers Deep Cave and Baker Creek as shown previously by other researchers using dye. The water chemistry data support a hydrologic connection between Baker Creek with Model Cave; however, a connection between the cave and Pole Canyon Creek remains unclear, partly as the result of a complicated flow path and passage network associated with the cave and surrounding terrain. Rosethorn Spring, the sampling point farthest downgradient in the upper Baker Creek drainage, showed chemical characteristics that do not preclude a possible connection to Baker Creek.
A residence time for water discharging into Model Cave could not be determined as samples of dissolved gases, required for the assessment, were not collected from the cave. The residence time of water discharging into Wheelers Deep Cave and from Rosethorn Spring was less than 25 years, suggesting relatively short flow paths.

A notable hydrologic connection exists between upper Snake Creek and Outhouse Spring where geochemical characteristics are nearly the same and only a slight increase in constituent concentrations occurred due to water-alluvium interaction prior to water discharging from the spring. The slight increase in constituent concentrations relative to Snake Creek water is likely due to the relatively short residence time (less than 25 years) of the water underground. The water collected from Squirrel Spring Cave had a relatively high sumof-constituents concentration as evidenced by the relatively high chloride concentrations found in the sample. Given the relatively short estimated residence time for the water from Squirrel Spring Cave (15 to 20 years), the observed increases had to occur quickly, in a geological sense, before the water was discharged into the cave. The relatively high sum-ofconstituents and chloride concentrations may be due, at least in part, from the dissolution of salts and possibly transpiration occurring in areas upgradient of the cave. Outlet Spring may not be hydrologically connected to upper Snake Creek but rather may be recharged at high altitude within the Snake Creek drainage basin. These findings largely stem from the moderately high specific conductance, increased concentrations of chloride, strontium, and uranium, and the lightest $\delta \mathrm{D}$ and $\delta^{18} \mathrm{O}$ values of any other sample collected as part of this study. The estimated residence time for water sampled from Outlet Spring was also the longest calculated for any other site as part of this study, at 60 to 90 years. Spring Creek Spring discharges from the karst bedrock, which is substantiated by the geochemical characteristics of water sampled from this site and the somewhat short residence time of less than 30 years. 


\section{References Cited}

Acheampong, S.Y., 1992, Isotope hydrology of Lehman and Baker Creek drainages, Great Basin National Park, Nevada: Las Vegas, University of Nevada, Department of Geoscience, M.S. Thesis, $105 \mathrm{p}$.

Aeschbach-Hertig, W., Peeters, F., Beyerle, U., and Kipfer, R., 1999, Interpretation of dissolved atmospheric noble gases in natural waters: Water Resources Research, v. 35, no. 9, p. 2779-2792.

Brenton, R.W., and Arnett, T.L., 1993, Methods of analysis by the U.S. Geological Survey National Water Quality Laboratory-Determination of dissolved organic carbon by uvpromoted persulfate oxidation and infrared spectrometry: U.S. Geological Survey Open-File Report 92-480, 12 p.

Bridgemon, R.R., 1966, Hydrological observations in the Baker Creek cave system, White Pine County, Nevada: Tucson, Arizona, University of Arizona Association of Cavers, National Speleological Society, Arizona Caver, v. 3, no. 2, p. $20-36$.

Clark, I.D., and Fritz, Peter, 1997, Environmental isotopes in hydrogeology: Lewis Publishers, New York, 328 p.

Coplen, T.B., 2011, Guidelines for the reporting of stable hydrogen, carbon, and oxygen isotope-ratio data: U.S. Geological Survey, Isotope Tracers Project, Resources on Isotopes, Guidelines for reporting stable isotope data, accessed August 11, 2011, http://wwwrcamnl.wr.usgs.gov/ isoig/res/guide.html.

Craig, Harmon, 1961, Isotopic variations in meteoric water: Science, v. 133, no. 3465, p. 1702-1703.

Elliott, P.E., Beck, D.A., and Prudic, D.E., 2006, Characterization of surface-water resources in the Great Basin National Park area and their susceptibility to ground-water withdrawals in adjacent valleys, White Pine County, Nevada: U.S. Geological Survey Scientific Investigations Report 20065099, $156 \mathrm{p}$. and $1 \mathrm{pl}$.

Fishman, M.J., ed., 1993, Methods of analysis by the U.S. Geological Survey National Water Quality LaboratoryDetermination of inorganic and organic constituents in water and fluvial sediments: U.S. Geological Survey OpenFile Report 93-125, 217 p.

Fishman, M.J., and Friedman, L.C., 1985, Methods for determination of inorganic substances in water and fluvial sediments: U.S. Geological Survey Open-File Report 85-495, $709 \mathrm{p}$.

Friedman, Irving, Smith, G.I., Johnson, C.A., and Moscati, R.J., 2002, Stable isotope composition of waters in the Great Basin, United States, 2. Modern precipitation: Journal of Geophysical Research, v. 107, 22 p.
Gibs, Jacob, Wilde, F.D., and Heckathorn, H.A., 2007, Use of multiparameter instruments for routine field measurements: U.S. Geological Survey Techniques of Water-Resources Investigations, book 9, chap. A6., sec. 6.8, August 2007, accessed September 5, 2011, http://pubs.water.usgs.gov/ twri9A6/.

Halford, K.J., and Plume, R.W., 2011, Potential effects of groundwater pumping on water levels, phreatophytes, and spring discharges in Spring and Snake Valleys, White Pine County, Nevada, and adjacent areas in Nevada and Utah: U.S. Geological Survey Scientific Investigations Report 2011-5032, $52 \mathrm{p}$.

Harrill, J.R., and Prudic, D.E., 1998, Aquifer systems in the Great Basin region of Nevada, Utah, and adjacent statesSummary report: U.S. Geological Survey Professional Paper 1409-A, 66 p.

Hem, J.D., 1992, Study and interpretation of the chemical characteristics of natural water: U.S. Geological Survey WaterSupply Paper 2254, 263 p.

Hershey, R.L., Heilweil, V.M., Gardner, Philip, Lyles, B.F., Earman, Sam, Thomas, J.M., and Lundmark, K.W., 2007, Ground-water chemistry interpretations supporting the Basin and Range carbonate-rock aquifer system (BARCAS) study, eastern Nevada and western Utah: Desert Research Institute, Nevada System of Higher Education and the U.S. Geological Survey, DHS Publication No. 41230, 86 p.

Hood, J.W., and Rush, F.E., 1965, Water-resources appraisal of the Snake Valley area, Utah and Nevada: Utah State Engineer Technical Publication 14, 43 p.

Hose, R.K., and Blake, M.C., Jr., 1976, Geology and mineral resources of White Pine County, Nevada, Part I. Geology: Nevada Bureau of Mines and Geology, Mackay School of Mines, University of Nevada, Reno, Bulletin 85, p. 1-35.

Keeling, R.F., Piper, S.C., Bollenbacker, A.F., and Walker, S.J., 2010a, Monthly atmospheric ${ }^{13} \mathrm{C} /{ }^{12} \mathrm{C}$ isotopic ratios for 11 SIO stations (LaJolla, California), in Trends: A compendium of data on global change: Carbon Dioxide Information Analysis Center, Oak Ridge National Laboratory, U.S. Department of Energy, Oak Ridge, Tennessee, U.S.A., http://cdiac.ornl.gov/ftp/trends/co2/iso-sio/SIO_La_ Jolla_13CO2.txt.

Keeling, R.F., Piper, S.C., Bollenbacker, A.F., and Walker, S.J., 2010b, Monthly atmospheric ${ }^{13} \mathrm{C} /{ }^{12} \mathrm{C}$ isotopic ratios for 11 SIO stations (Alert Canada), in Trends: A compendium of data on global change: Carbon Dioxide Information Analysis Center, Oak Ridge National Laboratory, U.S. Department of Energy, Oak Ridge, Tennessee, U.S.A., http://cdiac. ornl.gov/ftp/trends/co2/iso-sio/SIO_Alert_13CO2.txt. 
Kipfer, R., Aeschbach-Hertig, W., Peeters, F., and Stute, M., 2002, Noble gases in lakes and ground waters: Reviews in Mineralogy and Geochemistry, v. 47, p. 615-700.

Koterba, M.T., Wilde, F.D., and Lapham, W.W., 1995, Groundwater data-collection protocols and procedures for the National Water-Quality Assessment Program: Collection and documentation of water-quality samples and related data: U.S. Geological Survey Open-File Report 95-399, 113 p.

Lange, A.L., 1958, Stream piracy and cave development along Baker Creek, Nevada: Western Speleological Institute, Bulletin No. 1, 20 p.

Lee, D.E., and Christiansen, E.H., 1983, The mineralogy of the Snake Creek-Williams Canyon pluton, southern Snake Range, Nevada: U.S. Geological Survey Open-File Report 83-337, 21 p.

Lee, D.E., Kistler, R.W., and Robinson, A.C., 1986, The strontium isotope composition of granitoid rocks of the southern Snake Range, Nevada, in Peterman, Z.E., and Schnabel, D.C., eds., Shorter contributions to isotope research: U.S. Geological Survey Bulletin 1622, p. 171-179.

Lee, D.E., and Van Loenen, R.E., 1971, Hybrid granitoid rocks of the southern Snake Range, Nevada: U.S. Geological Survey Professional Paper 668, 48 p.

Lewis, M.E., 2006, Dissolved oxygen (ver. 2.1): U.S. Geological Survey Techniques of Water-Resources Investigations, book 9, chap. A6., sec. 6.2, June 2006, accessed September 5, 2011, http://water.usgs.gov/owq/FieldManual/Chapter6/ Archive/6.2_v2.1.9102013.pdf.

Manning, A.H., 2008, Ground-water temperature, noble gas, and carbon isotope data from the Espanola Basin, New Mexico: U.S. Geological Survey Scientific Investigations Report 2008-5200, 69 p.

Miller, E.L., Dumitru, T.A., Brown, R.W., and Gans, P.B., 1999, Rapid Miocene slip on the Snake Range-Deep Creek Range fault system, east-central Nevada: Geological Society of America Bulletin, v. 111, no. 6, p. 886-905.

Misch, Peter, and Hazzard, J.C., 1962, Stratigraphy and metamorphism of late Precambrian rocks in central northeastern Nevada and adjacent Utah: American Association of Petroleum Geologists Bulletin, v. 46, no. 3, p. 289-343.

Mueller, D.K., Martin, J.D., and Lopes, T.J., 1997, Qualitycontrol design for surface-water sampling in the National Water-Quality Assessment Program: U.S. Geological Survey Open-File Report 97-223, 17 p.

O’Dell, J.W., Pfaff, J.D., Gales, M.E., and McKee, G.D., 1984, The determination of inorganic anions in water by ion chromatography — method 300.0: U.S. Environmental Protection Agency, Research and Development, Environmental Monitoring and Support Laboratory, EPA-600/4-84-017, 5 p.
O’Leary, M.H., 1988, Carbon isotopes in photosynthesis: BioScience, v. 38, no. 5, p. 328-336.

Plummer, L.N., and Busenberg, Eurybiades, 2011, Chlorofluorocarbons background - Excerpt from Cook, P.G., and Herczeg, A.L., eds., Environmental tracers in subsurface hydrology: Boston, Kluwer Academic Press, p. 441-478, accessed August 10, 2011, http://water.usgs.gov/lab/ chlorofluorocarbons/background/.

Prudic, D.E., and Glancy, P.A., 2009, Geochemical investigation of source water to Cave Springs, Great Basin National Park, White Pine County, Nevada: U.S. Geological Survey Scientific Investigations Report 2009-5073, 28 p.

Radtke, D.B., Davis, J.V., and Wilde, F.D., 2005, Specific electrical conductance (ver. 1.2): U.S. Geological Survey Techniques of Water-Resources Investigations, book 9, chap. A6., sec. 6.3, August 2005, accessed September 5, 2011, http://pubs.water.usgs.gov/twri9A6/.

Ritz, G.F., and Collins, J.A., 2008, pH (ver. 2.0): U.S. Geological Survey Techniques of Water-Resources Investigations, book 9, chap. A6., sec. 6.4, October 2008, accessed September 5, 2011, http://pubs.water.usgs.gov/twri9A6/.

Rounds, S.A., 2006, Alkalinity and acid neutralizing capacity (ver. 3.0): U.S. Geological Survey Techniques of WaterResources Investigations, book 9, chap. A6., sec. 6.6, July 2006, accessed September 5, 2011, http://pubs.water.usgs. gov/twri9A6/.

Rush, F.E., and Kazmi, S.A.T., 1965, Water-resources appraisal of Spring Valley, White Pine and Lincoln Counties, Nevada: Nevada Department of Conservation and Natural Resources Water Resources Reconnaissance Report $33,39 \mathrm{p}$.

Schwarzenbach, R.P., Gschwend, P.M., and Imboden, D.M., 1993, Environmental organic chemistry: John Wiley and Sons, Inc., New York, p. 109-123.

Stewart, J.H., 1980, Geology of Nevada-A discussion to accompany the geologic map of Nevada: Nevada Bureau of Mines and Geology Special Publication 4, 136 p.

Stute, Martin, and Schlosser, Peter, 2001, Atmospheric noble gases, in Cook, P.G., and Herczeg, A.L., eds., Environmental tracers in subsurface hydrology: Boston, Kluwer Academic Publishers, p. 349-377.

U.S. Geological Survey, 2006, Collection of water samples (ver. 2.0): U.S. Geological Survey Techniques of WaterResources Investigations, book 9, chap. A4, September 2006, accessed September 5, 2011, http://pubs.water.usgs. gov/twri9A4/. 
U.S. Geological Survey, 2008, Instructions for collecting samples: Reston Stable Isotope Laboratory, Isotope Fractionation Project, accessed August 11, 2009, http://isotopes.usgs.gov/lab/instructions.html.

U.S. Geological Survey, 2009a, Instructions for collecting samples, C-13/C-12 of dissolved inorganic carbon in water precipitated as strontium carbonate: Reston Stable Isotope Laboratory, Isotope Fractionation Project, accessed August 25, 2009, http://isotopes.usgs.gov/lab/instructions.html.

U.S. Geological Survey, 2009b, Dissolved gas $\mathrm{N}_{2} / \mathrm{Ar}$ and $4 \mathrm{He}$ sampling instructions: Reston Chlorofluorocarbon Laboratory, Reston, Virginia, accessed December 1, 2011, http://water.usgs.gov/lab/dissolved-gas/sampling.

Western Region Climate Center, 2011, Great Basin National Park, Nevada (263340): Period of record monthly climate summary (7/1/1948 to 12/31/2010), accessed August 10, 2011, http://www.wrcc.dri.edu/cgi-bin/cliMAIN.pl?nv3340.
Whitebread, D.H., 1969, Geologic map of the Wheeler Peak and Garrison quadrangles, Nevada and Utah: U.S. Geological Survey Miscellaneous Geologic Investigations Map I-578, scale 1:48,000.

Wilde, F.D., ed., 1999, Collection of water samples: U.S. Geological Survey National Field Manual for the collection of water-quality data, chap. A4, Techniques of WaterResources Investigations 09-A4, 231 p.

Wilde, F.D., 2006, Temperature (version 2): U.S. Geological Survey Techniques of Water-Resources Investigations, book 9, chap. A6, sec. 6.1, March 2006, accessed September 5, 2011, http://pubs.water.usgs.gov/twri9A6/.

Wilde, F.D., Radtke, D.B., Gibs, Jacob, and Iwatsubo, R.T., eds., 2004, Processing of water samples (ver. 2.2): U.S. Geological Survey Techniques of Water-Resources Investigations, book 9, chap. A5, April 2004, accessed September 5, 2011, http://pubs.water.usgs.gov/twri9A5/. 


\section{Appendix 1}

\section{Appendix 2}

Table 1-1. Summary of certificate of analysis for blank water used to process equipment blanks associated with sampling water from selected streams, springs, and caves in the upper Baker and Snake Creek drainages in Great Basin National Park, Nevada, February 2009.

[Abbreviations: $\mathrm{mg} / \mathrm{L}$, milligrams per liter; $\mu \mathrm{S} / \mathrm{cm}$, microsiemens per centimeter; ${ }^{\circ} \mathrm{C}$, degrees Celsius; $\mu \mathrm{g} / \mathrm{L}$, micrograms per liter]

\begin{tabular}{rcc}
\hline \multicolumn{1}{c}{ Parameter or Constituent (units) } & Maximum Allowable Limit & Result \\
\hline Appearance & Clear and odorless & passed \\
Chloride $(\mathrm{mg} / \mathrm{L})$ & 0.001 & passed \\
Specific conductance $\left(\mu \mathrm{S} / \mathrm{cm}\right.$ at $\left.25^{\circ} \mathrm{C}\right)$ & 0.056 & passed \\
\hline Heavy metals $($ as lead, $\mu \mathrm{g} / \mathrm{L})$ & 10 & passed \\
Nitrate $(\mathrm{mg} / \mathrm{L}$ as nitrate $)$ & 0.2 & passed \\
\hline Total organic carbon $(\mu \mathrm{g} / \mathrm{L})$ & 50 & passed \\
\hline Phosphate $(\mathrm{mg} / \mathrm{L}$ as phosphate) & 1 & passed \\
\hline Silica $(\mathrm{mg} / \mathrm{L}$ as silicon dioxide $)$ & 0.003 & passed \\
Sodium $(\mathrm{mg} / \mathrm{L})$ & 0.001 & passed \\
Sulfate $(\mathrm{mg} / \mathrm{L})$ & 1 & passed \\
\hline
\end{tabular}

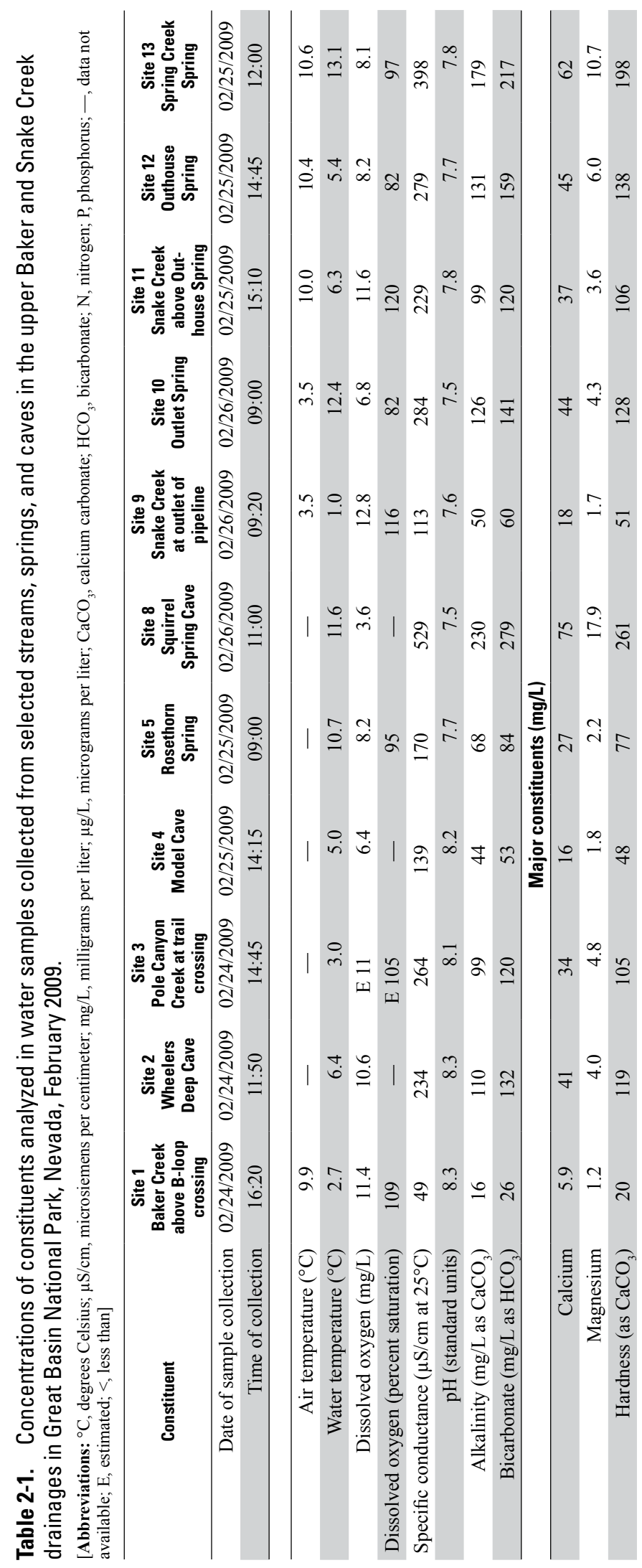




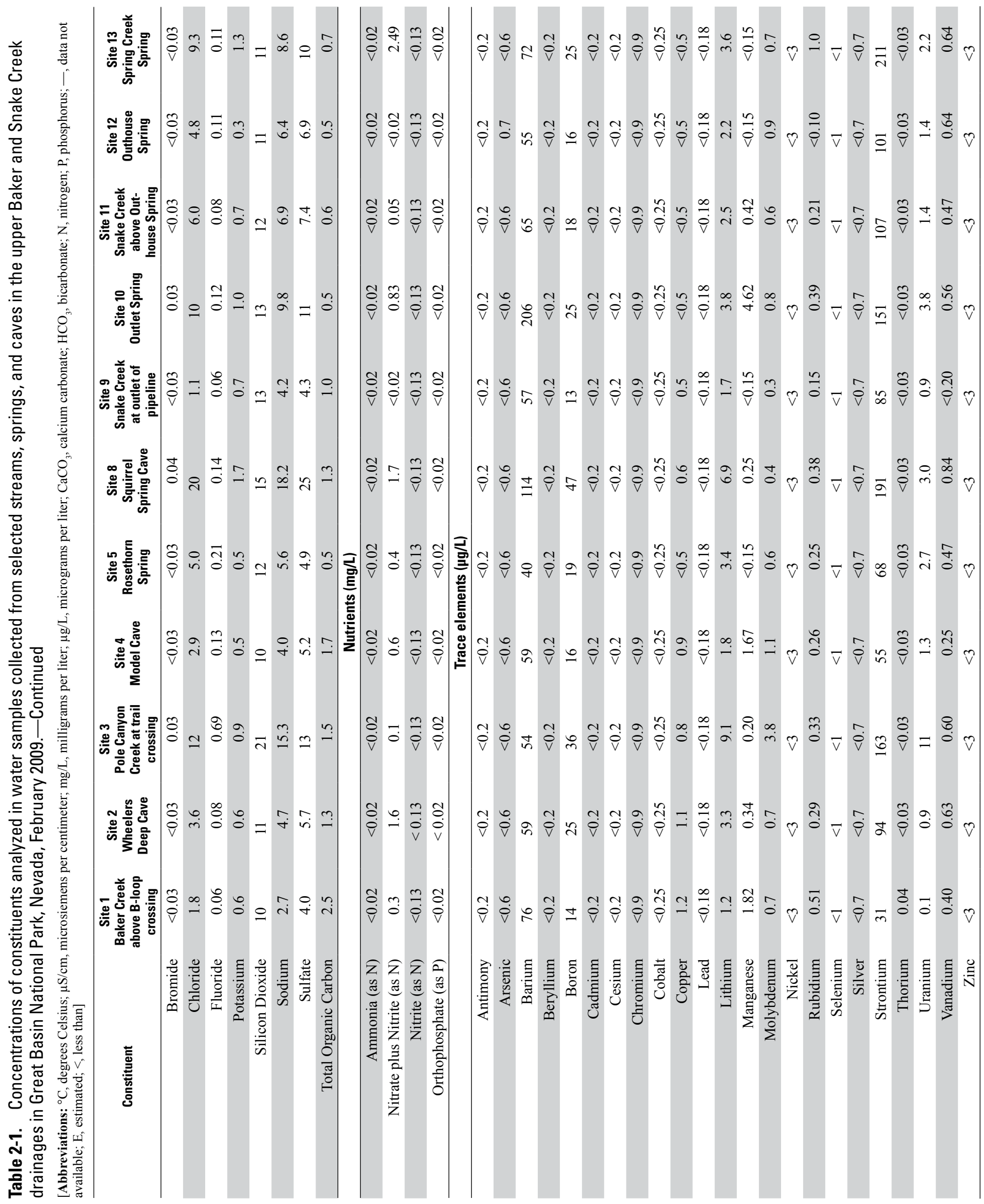




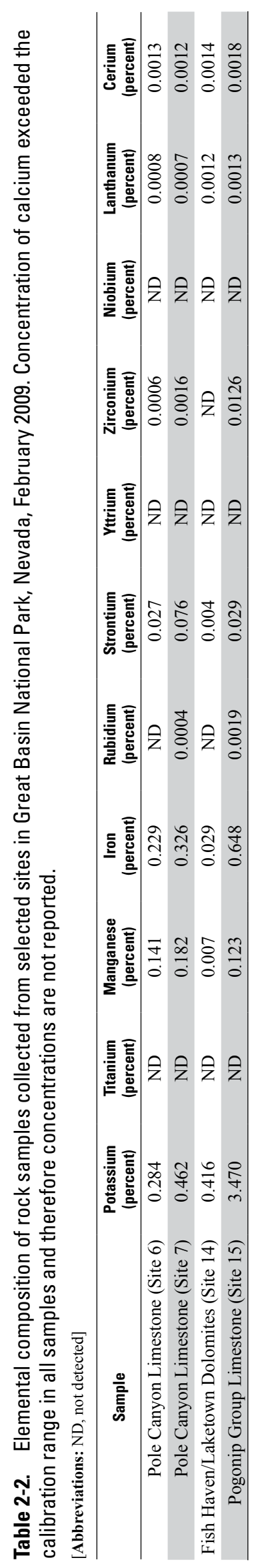




